\title{
Template-Directed Synthesis of Multiply Mechanically Interlocked Molecules Under Thermodynamic Control
}

\author{
Fabio Aricó, Theresa Chang, Stuart J. Cantrill, Saeed I. Khan, and J. Fraser Stoddart*[a]
}

\begin{abstract}
The template-directed construction of crown-ether-like macrocycles around secondary dialkylammonium ions $\left(\mathrm{R}_{2} \mathrm{NH}_{2}{ }^{+}\right)$has been utilized for the expedient (one-pot) and highyielding synthesis of a diverse range of mechanically interlocked molecules. The clipping together of appropriately designed dialdehyde and diamine compounds around $\mathrm{R}_{2} \mathrm{NH}_{2}{ }^{+}$-containing dumbbell-shaped components proceeds through the formation, under thermodynamic control, of imine bonds. The reversible nature of this particular reaction confers the benefits of "errorchecking" and "proof-reading", which one usually associates with supramolecular chemistry and strict self-assembly processes, upon these wholly molecular
\end{abstract}

systems. Furthermore, these dynamic covalent syntheses exploit the efficient templating effects that the $\mathrm{R}_{2} \mathrm{NH}_{2}{ }^{+}$ ions exert on the macrocyclization of the matched dialdehyde and diamine fragments, resulting not only in rapid rates of reaction, but also affording near-quantitative conversion of starting materials into the desired interlocked products. Once assembled, these "dynamic" interlocked compounds can be "fixed" upon reduction of the reversible imine bonds (by using $\mathrm{BH}_{3} \cdot \mathrm{THF}$ )

Keywords: dynamic covalent chemistry $\cdot$ imine formation $\cdot$ molecular recognition • noncovalent interactions $\cdot$ reductive amination to give kinetically stable species, a procedure that can be performed in the same reaction vessel as the inital thermodynamically controlled assembly. Isolation and purification of the mechanically interlocked products formed by using this protocol is relatively facile, as no column chromatography is required. Herein, we present the synthesis and characterization of 1) a [2]rotaxane, 2) a [3] rotaxane, 3) a branched [4]rotaxane, 4) a bis [2]rotaxane, and 5) a novel cyclic [4]rotaxane, demonstrating, in incrementally more complex systems, the efficacy of this one-pot strategy for the construction of interlocked molecules.

\section{Introduction}

For the past 45 years now, the synthesis of exotic molecular compounds, such as catenanes, ${ }^{[1]}$ rotaxanes, ${ }^{[2]}$ knots, ${ }^{[3]}$ and Borromean rings, ${ }^{[4,5]}$ with aesthetically appealing ${ }^{[5]}$ and potentially useful ${ }^{[6]}$ structures have been proceeding apace. During the same period of time, the synthetic protocols employed by chemists have evolved from being all but statisti$\mathrm{cal}^{[7]}$ in the beginning, to progressively covalent, ${ }^{[8]}$ coordina-

[a] Dr. F. Aricó, Dr. T. Chang, Dr. S. J. Cantrill, Dr. S. I. Khan, Prof. J. F. Stoddart

California NanoSystems Institute and

Department of Chemistry and Biochemistry

University of California, Los Angeles

405 Hilgard Avenue, Los Angeles, CA 90095-1569 (USA)

Fax: $(+1) 310-206-1843$

E-mail: stoddart@chem.ucla.edu

Supporting information for this article is available on the WWW

under http://www.chemeurj.org/ or from the author. tive ${ }^{[9]}$ and noncovalent ${ }^{[10]}$ templating ${ }^{[11]}$ strategies under both kinetic ${ }^{[12]}$ and thermodynamic ${ }^{[13-17]}$ control.

In general, the syntheses of interlocked and intertwined molecular compounds that rely upon coordinative and noncovalent templating strategies come about with the aid of molecular-recognition motifs ${ }^{[18]}$ that induce the self-assembly ${ }^{[19]}$ of certain components to first of all form a complex. Although the formation of such complexes are more often than not under thermodynamic control, the final and crucial step in the synthesis of compounds with one or more mechanical bonds is usually kinetically controlled. This sequence of events has been described ${ }^{[20]}$ as supramolecular assistance to covalent synthesis. One hopes the majority of the final product, which is kinetically "fixed", is the desired product, for, if not, there is no going back from unwanted byproducts lacking mechanical bonds. In essence, the fate of the synthesis is sealed once and for all.

Dynamic covalent chemistry ${ }^{[21]}$ has been exploited in the template-directed syntheses ${ }^{[11]}$ of both catenanes ${ }^{[16,17]}$ and rotaxanes ${ }^{[16,17]}$ and it comes into its own in the construction of 
more intricate mechanically interlocked molecular compounds. ${ }^{[5,6]}$ The chief attribute of the thermodynamic approach over the kinetic one is the fact that the former operates under equilibrium control. As such, the formation of undesired kinetic byproducts can be recycled in the direction of the most stable mechanically interlocked molecular compound. Proof reading and error checking operate in conjunction with synthesis in a remarkably efficient manner. Numerous successes ${ }^{[15-17]}$ during the past 10 years have demonstrated the potential of dynamic covalent chemistry ${ }^{[21]}$ for synthesizing compounds consisting of two or more components that are associated with one another by virtue of mechanical linkages only. Particularly when it is template-directed, ${ }^{[11]}$ the appeal of this particular brand of synthesis lies in the fact that dynamic covalent bonds combine the robustness of covalent bonds with the reversibility of noncovalent bonding. And so it is for these reasons that the reversible and/or exchangeable character of acetal, ${ }^{[13]}$ ester, ${ }^{[14]}$ and disulfide $^{[15]}$ bond formation, of labile metal-ligand coordination $^{[16]}$ and carbon-carbon bond formation during metathesis $^{[17]}$ have, among others, played a key role in the development of the chemistry of the mechanical bond.

Despite the fact that there are now numerous examples $^{[13,15-18]}$ reported in the literature describing the use of reversible reactions for the preparation of [2]catenanes and [2]rotaxanes, the application of dynamic covalent chemistry ${ }^{[21]}$ to the construction of higher order catenanes and rotaxanes, as well as mechanically interlocked compounds beyond catenanes and rotaxanes, ${ }^{[2]}$ has remained largely unexplored $^{[23]}$ up until imine bond ${ }^{[24]}$ formation and exchange (Scheme 1) was exploited by us. ${ }^{[25,26]}$ Following our recent

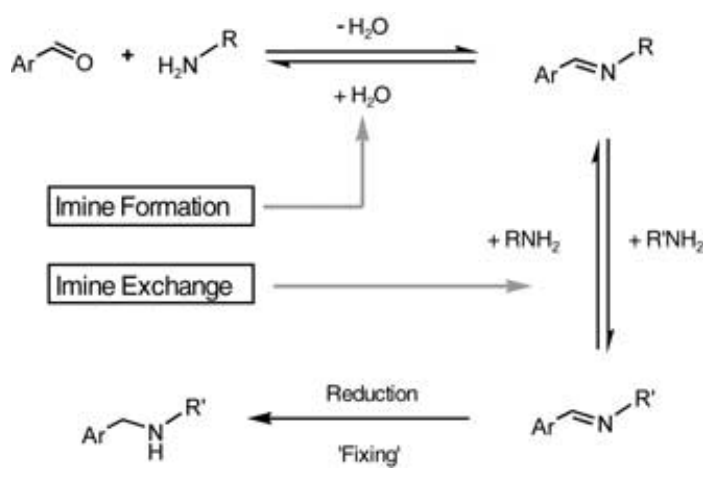

Scheme 1. An example of imine formation, exchange and reduction ("fixing").

demonstration $^{[4,5]}$ of the near-quantitative self-assembly of a Borromean ring compound from 18 components by the template-directed formation of 12 imine and 30 dative bonds associated with the coordination of three interlocked macrocycles, each tetranucleating and decadentate overall to a total of six zinc(II) ions, our confidence in the ability of imine chemistry to further the structural potential ${ }^{[27]}$ of the mechanical bond is considerable. When an imine bond is formed by the condensation of an amine with an aldehyde, water is produced. In the presence of water, the reaction is reversible, that is, the imine is hydrolyzed to give back its amine and aldehyde precursors. In the presence of another amine, imines can undergo reversible exchange reactions to yield different imines. ${ }^{[26,27]}$ Finally, the imine bonds can be "fixed" by reducing them to secondary amines that are kinetically stable.

In our first investigations ${ }^{[25,26]}$ of [2]rotaxane formation under thermodynamic control, we used dynamic dumbbell components, in which both stoppers were attached to the rod section by imine bonds, in the presence of matching ring components. The yields of the rotaxanes never exceeded $50 \%$. By contrast, a more efficient pathway for the formation of a [2]rotaxane involves a clipping process ${ }^{[28,29]}$ in which a kinetically stable dumbbell component recognizes and binds the macrocyclic precursors and, in so doing, templates the formation of the macrocycle around the dumbbell component. The dynamic pathway that prevails during the formation of such a macrocycle containing two imine bonds ${ }^{[28]}$ is much more efficient, with the outcomes being near-quantitative ones. In competition experiments, kinetic control is often found ${ }^{[29]}$ to dominate in the initial stages of a reaction, giving way to thermodynamic control in the fullness of time.

The repercussions of going from forming two imine bonds remote from the recognition site in a dialkylammonium ion/ crown ether based rotaxane to one in which the secondary dialkylammonium center facilitates the formation of the two imine bonds is illustrated graphically in Figure 1. In the first

a)

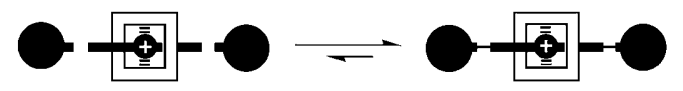

b)

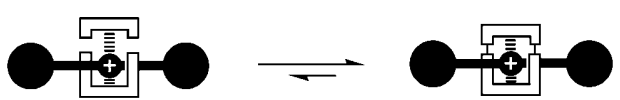

Figure 1. Formation of a [2]rotaxane a) by a dynamic-stoppering and b) by a dynamic-clipping approach.

case, imine bond formation is not activated during the process of mechanical bond construction, whereas in the second case, the formation of the two imine bonds is part of the templation process leading to rotaxane formation.

In this full paper, we report the template-directed syntheses (in all cases $>95 \%$ ) and characterization by mass spectrometry in the gas phase and by NMR spectroscopy in solution of 1) a [3] rotaxane (with X-ray crystal structure), 2) a branched [4]rotaxane, 3) a bis[2]rotaxane (with X-ray crystal structure) and 4) a novel, jumbo-sized cycle incorporating a bismacrocycle mechanically interlocked with a bisammonium dication. In addition, we announce the use of $\mathrm{BH}_{3} \cdot \mathrm{THF}$ to "fix" the thermodynamically stable products as kinetically stable ones without the need for time-consuming purification procedures, such as chromatography: yields of $75-96 \%$ are reported. 


\section{Results and Discussion}

In 2001 we reported ${ }^{[28]}$ the synthesis of the [2]rotaxane [4$\mathrm{H}] \mathrm{PF}_{6}$ as outlined in Scheme 2. In this template-directed ${ }^{[11]}$ reaction, a macrocyclic diimine with a $[24]$ crown- 8 construc- toxicity of $\mathrm{BH}_{3} \cdot$ lutidine, which has led to its removal from the market, and purification procedures, which become increasingly difficult to perform with higher order rotaxanes, were limiting the exploitation of this otherwise efficient imine clipping protocol for the construction of more com-

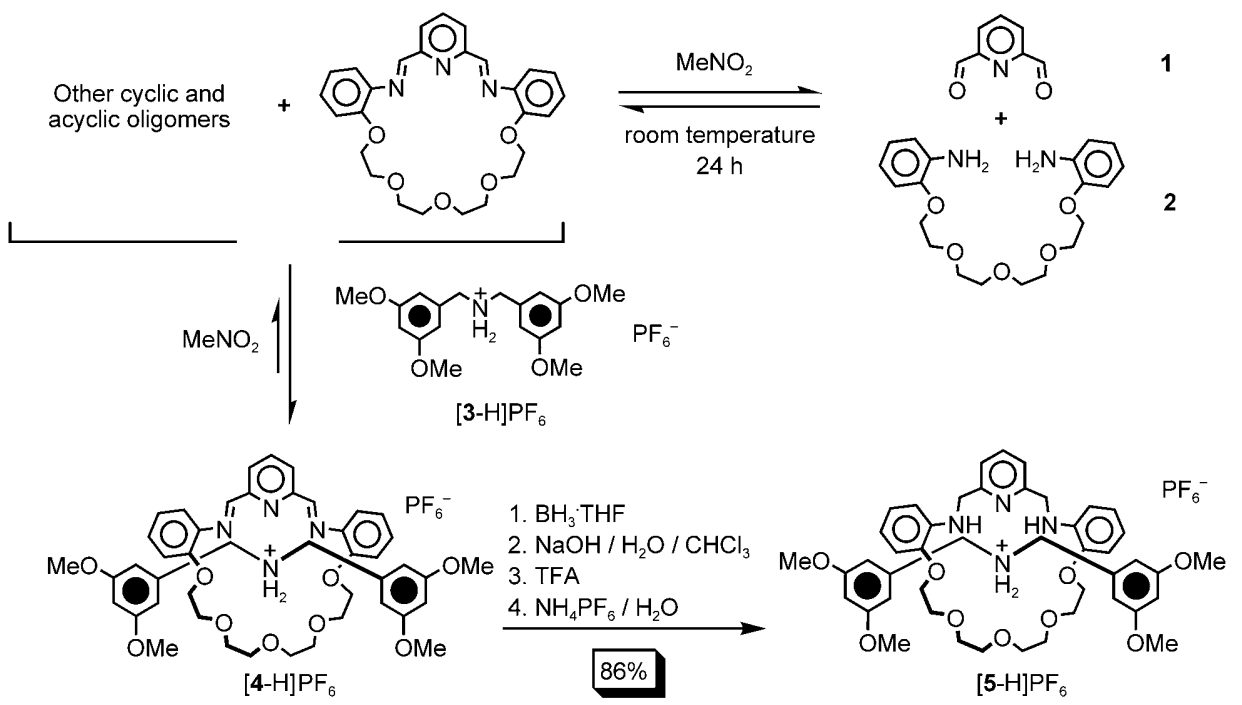

Scheme 2. Synthesis of the [2]rotaxane $[\mathbf{5}-\mathrm{H}] \mathrm{PF}_{6}$ by dynamic covalent chemistry.

plex mechanically interlocked molecular structures based upon the dialkylammonium ion/ crown ether recognition motif. ${ }^{[30]}$ We have found recently, however, that the $\mathrm{BH}_{3} \cdot \mathrm{THF}$ complex $\left(1.8 \mathrm{M} \mathrm{BH}_{3}\right.$ in THF) is an excellent substitute for $\mathrm{BH}_{3}$.lutidine for the reduction of imine bonds in thermodynamically labile compounds. When the formation and subsequent "fixing" of the dynamic [2]rotaxane [4-H] $\mathrm{PF}_{6}$ was repeated using $\mathrm{BH}_{3} \cdot \mathrm{THF}$ (ca. 2 equiv for each imine bond) complete reduction of the imine bonds was observed by ${ }^{1} \mathrm{H}$ NMR spectroscopy after only two hours instead of two days. Moreover, the kinetically stable [2] rotaxane [5-H] $\mathrm{PF}_{6}$ was

tion is formed by condensation in nitromethane $\left(\mathrm{MeNO}_{2}\right)$ of 2,6-pyridinedicarboxaldehyde (1) and tetraethyleneglycol bis(2-aminophenyl)ether (2) around bis(3,5-dimethoxybenzyl)ammonium hexafluorophosphate $\left([3-\mathrm{H}] \mathrm{PF}_{6}\right)$ as the active dumbbell. Well-resolved peaks were observed in the ${ }^{1} \mathrm{H}$ NMR spectrum of the reaction mixture, indicating that the [2]rotaxane [4-H] $\mathrm{PF}_{6}$ is by far the most thermodynamically stable product, presumably as a result of $\mathrm{N}^{+}-\mathrm{H} \cdots \mathrm{N}$ hydrogen bonding, $\mathrm{C}-\mathrm{H} \cdots \mathrm{O}$ interactions and, most likely, also aromatic $\pi \cdots \pi$ stacking interactions between the macrocyclic diimine and the active dumbbell component. ${ }^{[28]}$ The imine bonds in [2] rotaxane [4-H] $\mathrm{PF}_{6}$ were reduced with $\mathrm{BH}_{3}$ lutidine during a period of two days, to yield, after an involved workup procedure that included chromatography, the "fixed" [2]rotaxane [5-H] $\mathrm{PF}_{6}$ in $70 \%$ yield.

This protocol represents an efficient way of assembling a new class of mechanically interlocked molecular compounds from easily accessible starting materials. However, the acute isolated as a pure crystalline powder in $86 \%$ yield after deprotonation of the secondary dialkylammonium center by extraction with a mixture of aqueous sodium hydroxide solution and chloroform, followed by reprotonation of the residue from the chloroform extract with trifluoroacetic acid and anion exchange with a saturated aqueous solution of ammonium hexafluorophosphate. ${ }^{[31]}$ The purification procedure does not require any time-consuming chromatography.

When a similar experiment was carried out using dibenzylammonium hexafluorophosphate $[6-\mathrm{H}] \mathrm{PF}_{6}$ as the template, the components assembled spontaneously (Scheme 3 ) to form the pseudorotaxane $\left[\mathbf{7} \cdot \mathbf{6}-\mathrm{H}_{2}\right] \mathrm{PF}_{6}$. Reduction of the two imine bonds in [7.6- $\left.\mathrm{H}_{2}\right] \mathrm{PF}_{6}$ with $\mathrm{BH}_{3} \cdot \mathrm{THF}$ and deprotonation of the secondary dialkylammonium center of the template resulted in the isolation of the free macrocycle $\mathbf{8}$ in a yield of $80 \%$. The ${ }^{1} \mathrm{H}$ NMR spectrum (Figure 2) of the white crystalline product can be interpreted in terms of the constitution 8. Slow evaporation of a solution of $\mathbf{8}$ in di-

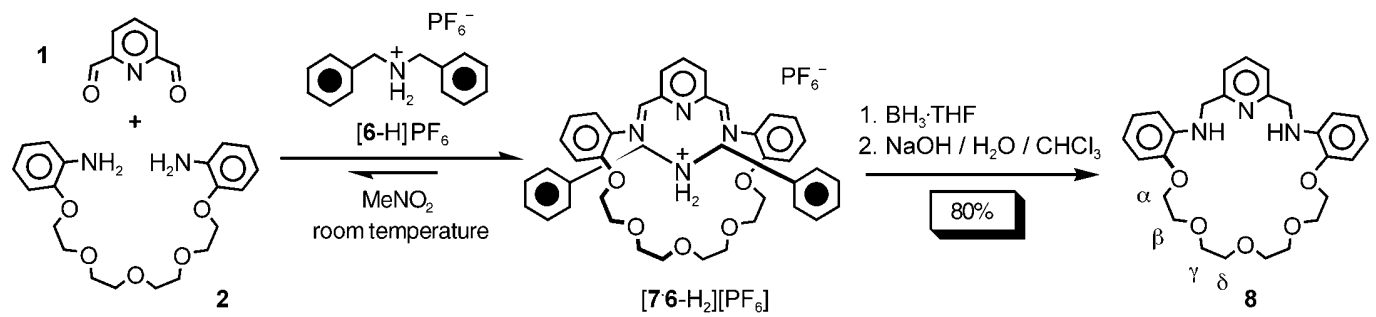

Scheme 3. Synthesis of the amine-based macrocycle $\mathbf{8}$. 


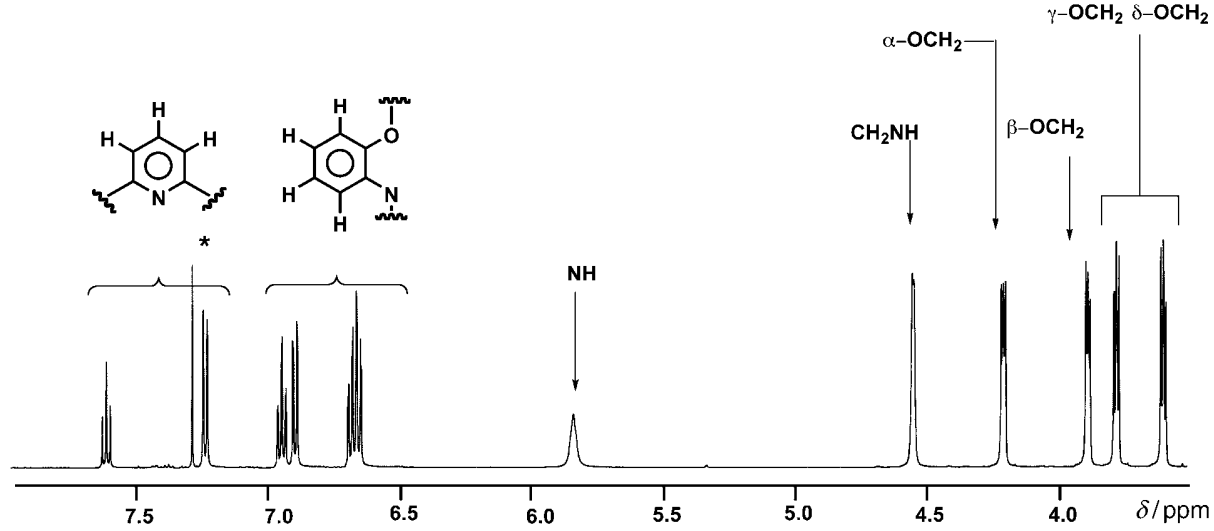

Figure 2. Partial ${ }^{1} \mathrm{H}$ NMR spectrum $(500 \mathrm{MHz})$ of the amine-based macrocycle 8

a syringe to this mixture and the reaction was monitored by ${ }^{1} \mathrm{H}$ NMR spectroscopy (Figure 4, bottom) until the peak associated with the four imine protons in the dynamic [3]rotaxane had disappeared $(4 \mathrm{~h})$ to yield $\left[\mathbf{1 0}-\mathrm{H}_{2}\right]\left[\mathrm{PF}_{6}\right]_{2}$. This compound was isolated as a pure crystalline powder in $80 \%$ yield after the deprotonation/ reprotonation procedure previously discussed. ${ }^{[32]}$ Single crystals, suitable for X-ray crystallography, were grown by liquid diffusion of EtOH into a solu-

chloromethane and hexane yielded single crystals suitable for X-ray crystallographic analysis (Figure 3) which established the structure of the macrocycle beyond any doubt.

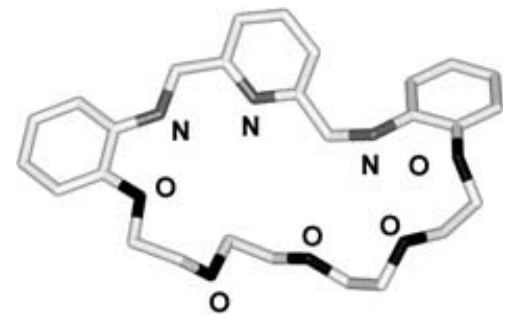

Figure 3. Solid-state structure of the macrocycle $\mathbf{8}$.

To establish the generality of this improved synthetic protocol, we have explored the synthesis of much more complex mechanically interlocked structures, such as a [3]rotaxane, a branched [4]rotaxane, and a bis[2]rotaxane. The bisammonium salt $\left[9-\mathrm{H}_{2}\right]\left[\mathrm{PF}_{6}\right]_{2}$ was obtained by using a well-established procedure ${ }^{[32]}$ from commercially available $p$-xylylenediamine and 3,5-dimethoxybenzaldehyde. Subsequent addition of two equivalents of each of $\mathbf{1}$ and $\mathbf{2}$ to [9$\left.\mathrm{H}_{2}\right]\left[\mathrm{PF}_{6}\right]_{2}$ in $\mathrm{CD}_{3} \mathrm{NO}_{2}$ resulted in the rapid assembly of a dynamic [3] rotaxane (Scheme 4), as indicated by the ${ }^{1} \mathrm{H}$ NMR spectrum (Figure 4, top) of the sample recorded after a few minutes. Immediately thereafter, $\mathrm{BH}_{3} \cdot \mathrm{THF}$ was added with tion of the [3]rotaxane $\left[\mathbf{1 0}-\mathrm{H}_{2}\right]\left[\mathrm{PF}_{6}\right]_{2}$ in $\mathrm{CHCl}_{3}$. Its solid-state structure (Figure 5) has crystallographic inversion symmetry. The inversion center lies at the middle of the $p$-phenylene ring in the dicationic dumbbell component. Each end of the centrosymmetric dumbbell component is threaded through the central cavity of one of the two ring components. Stabilization is achieved by a combination of $\mathrm{N}^{+}-\mathrm{H} \cdots \mathrm{N}, \mathrm{N}^{+-}$ $\mathrm{H} \cdots \mathrm{O}, \mathrm{C}-\mathrm{H} \cdots \mathrm{O}$ hydrogen-bonding and aromatic $\pi-\pi$ stacking interaction. The hydrogen atoms on both of the aminophenol-derived nitrogen atoms of the macrocycle were located by means of the difference maps and were found to be out-of-plane, giving a distorted tetrahedral geometry around both of these nitrogen atoms, which enter, one into $\mathrm{N}^{+}-\mathrm{H} \cdots \mathrm{N}$ hydrogen bonding, and the other into a $\mathrm{C}-\mathrm{H} \cdots \mathrm{N}$ interaction with the dumbbell component. The $\mathrm{NH}_{2}{ }^{+}$center in the dumbbell component has both of its hydrogen atoms involved in hydrogen bonding, one with the ether oxygen atom of the macrocycle and the other with an aminophenolderived nitrogen atom, as mentioned already. The centrosymmetric $p$-phenylene ring in the dumbbell is probably involved in rather weak $\pi-\pi$ stacking interactions (centroidcentroid separation, $4.72 \AA$ and mean inter-planar separation $4.15 \AA$ ) with one of the aminophenol-derived rings in each of the macrocyclic components. The planes of the two aromatic rings are inclined at approximately $18^{\circ}$ to each other.

Next, we applied the dynamic clipping-followed-by"fixing" methodology in the synthesis of a branched [4]ro-

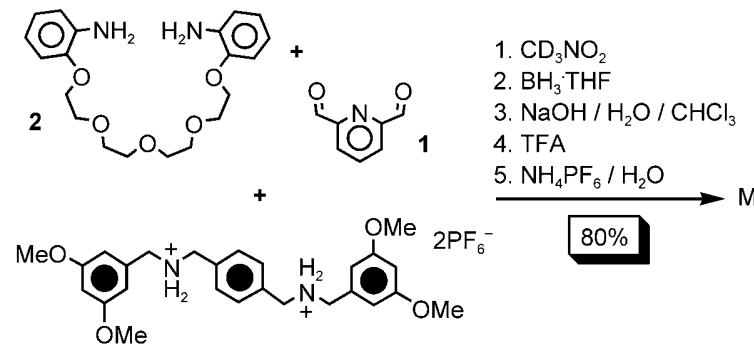

$\left[9-\mathrm{H}_{2}\right]\left[\mathrm{PF}_{6}\right]_{2}$

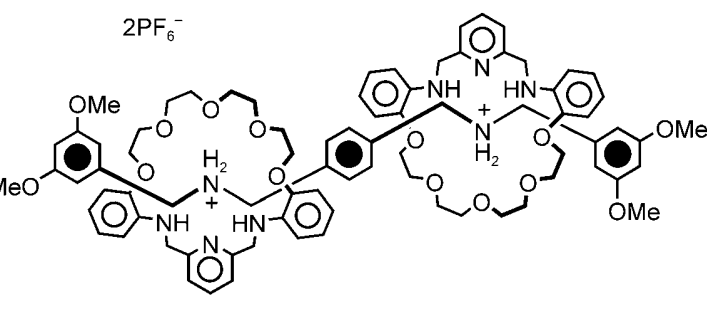

$\left[10-\mathrm{H}_{2}\right]\left[\mathrm{PF}_{6}\right]_{2}$

Scheme 4. Synthesis of the $[3]$ rotaxane $\left[\mathbf{1 0}-\mathrm{H}_{2}\right]\left[\mathrm{PF}_{6}\right]_{2}$. 


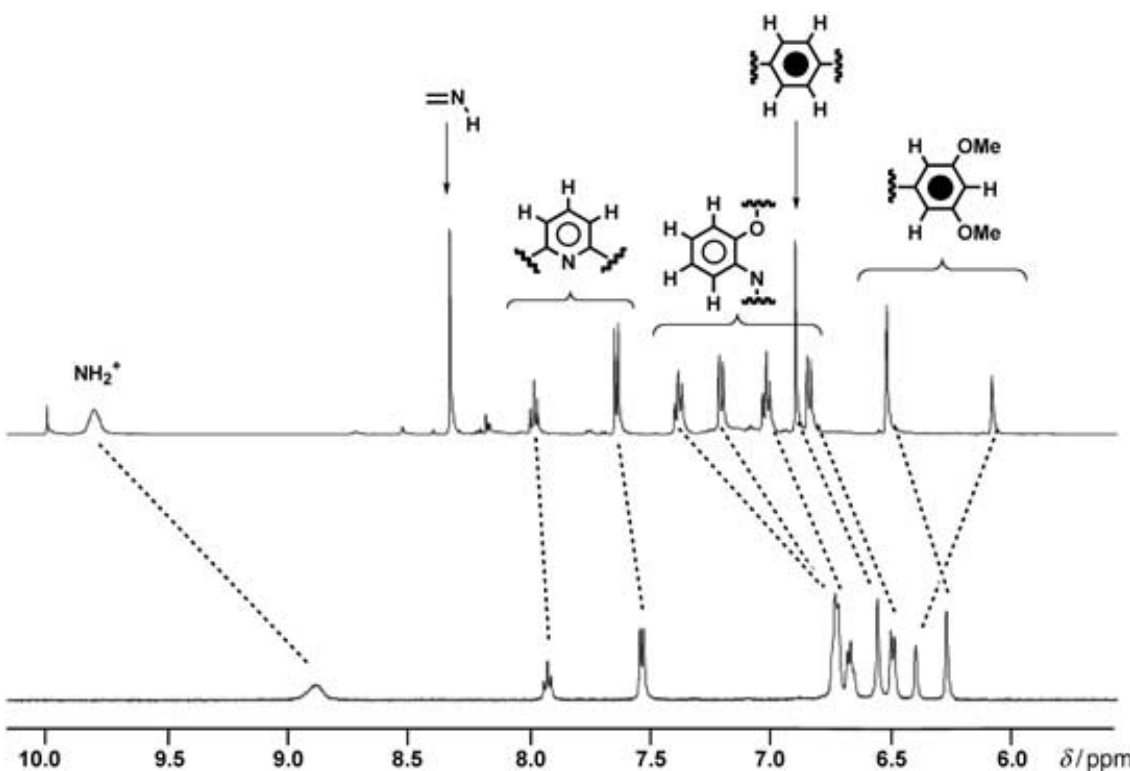

Figure 4. Partial ${ }^{1} \mathrm{H}$ NMR spectra $\left(500 \mathrm{MHz}, \mathrm{CD}_{3} \mathrm{NO}_{2}\right)$ of the dynamic [3] rotaxane formation (top) and of its related kinetically stable $[3]$ rotaxane $\left[\mathbf{1 0}-\mathrm{H}_{2}\right]\left[\mathrm{PF}_{6}\right]_{2}$ after reduction of the imine bonds (bottom).

taxane (Scheme 5). Using the trifurcated trisammonium salt ${ }^{[23]}$ $\left[\mathbf{1 1}-\mathrm{H}_{3}\right]\left[\mathrm{PF}_{6}\right]_{3}$ as a template and three equivalents of each of $\mathbf{1}$ and $\mathbf{2}$, it is possible to assemble the dynamic branched [4]rotaxane quickly $(5 \mathrm{~min}$ in $\mathrm{CD}_{3} \mathrm{NO}_{2}$ ) and efficiently (vide supra). The dynamic branched [4]rotaxane can be reduced readily with $\mathrm{BH}_{3} \cdot \mathrm{THF}$ to afford, after the usual workup, the kinetically stable $\left[\mathbf{1 2}-\mathrm{H}_{3}\right]-$ $\left[\mathrm{PF}_{6}\right]_{3}$ in an impressive $87 \%$ yield overall from a one-pot reaction. This conclusion was confirmed by ${ }^{1} \mathrm{H}$ NMR spectroscopy. Assignment of the proton resonances was consistent with the proposed structure for the branched [4]rotaxane [12- $\left.\mathrm{H}_{3}\right]-$ $\left[\mathrm{PF}_{6}\right]_{3}$. Moreover the high-resolution electrospray mass spec-

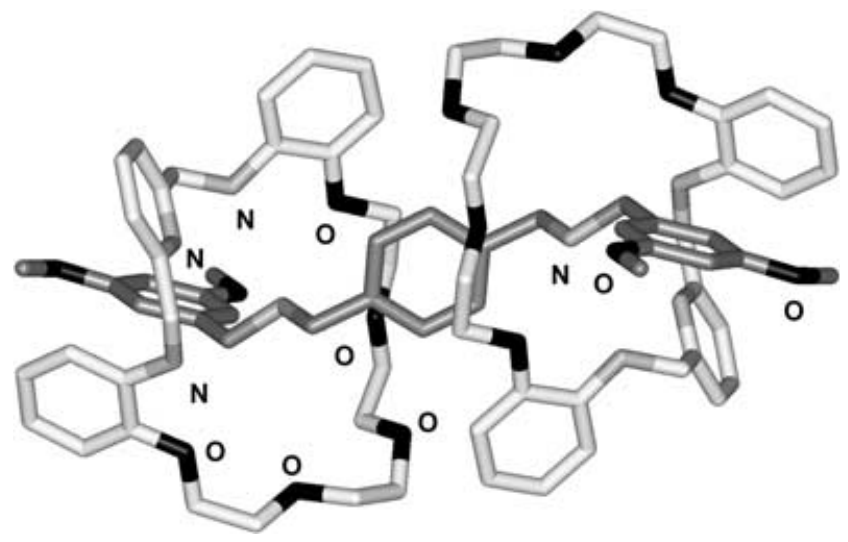

Figure 5. Solid-state structure of the $[3]$ rotaxane $\left[\mathbf{1 0}-\mathrm{H}_{2}\right]\left[\mathrm{PF}_{6}\right]_{2}$. trum of $\left[\mathbf{1 2}-\mathrm{H}_{3}\right]\left[\mathrm{PF}_{6}\right]_{3}$ is reproduced in Figure 6. A comparison between the calculated mass distribution for the triplycharged species and the experimental data confirms the authenticity of $\left[12-\mathrm{H}_{3}\right]\left[\mathrm{PF}_{6}\right]_{3}$.

The simple and efficient access to the branched [4]rotaxane is particularly interesting, since it opens the way to the convergent construction of mechanically interlocked dendrimers. ${ }^{[33]}$ Indeed, by using a 2,6-pyridinedicarboxaldehyde incorporating in its 4-position a dendritic wedge, it is possible to obtain dendrimers by the clipping-followed-by"fixing" approach in which each of the new branches is associated with a mechanically-bonded junction. ${ }^{[34]}$

With a branched [4]rotaxane coming within our grasp so easily, we were curious to see if we could make jumbo-sized

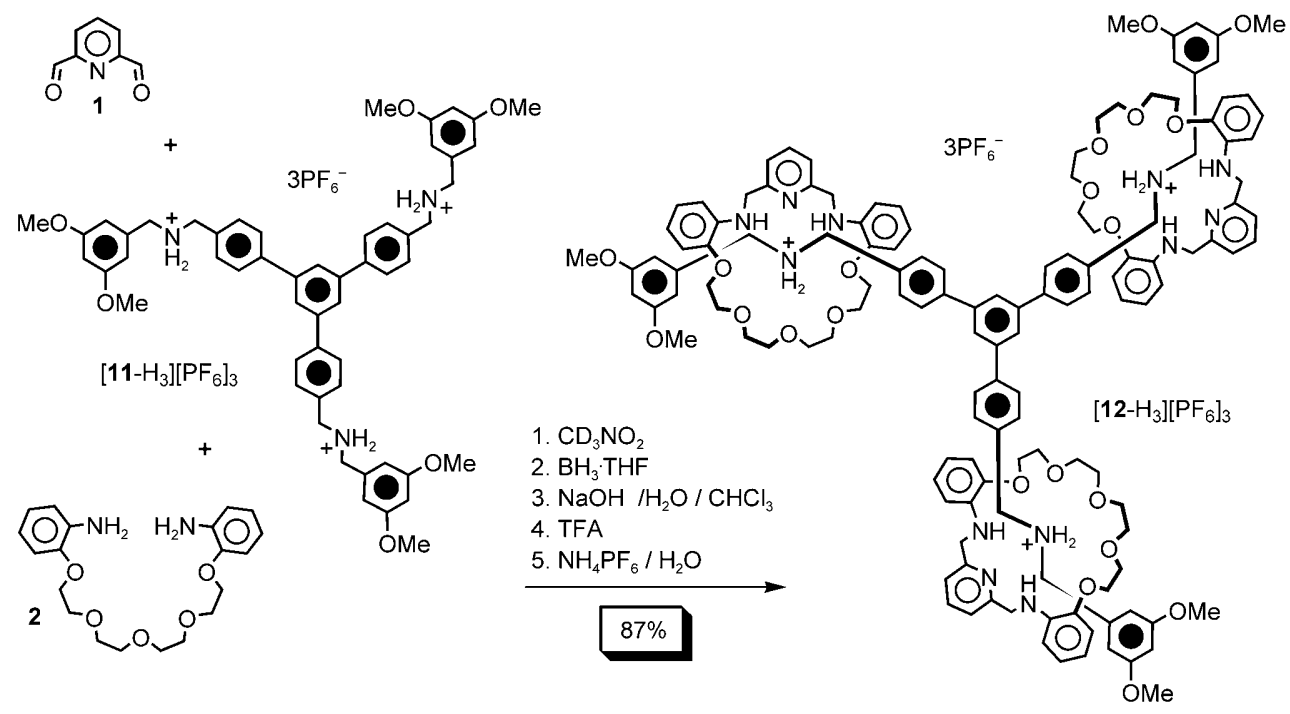

Scheme 5. Synthesis of the dendritic [4]rotaxane $\left[\mathbf{1 2}-\mathrm{H}_{3}\right]\left[\mathrm{PF}_{6}\right]_{3}$. 

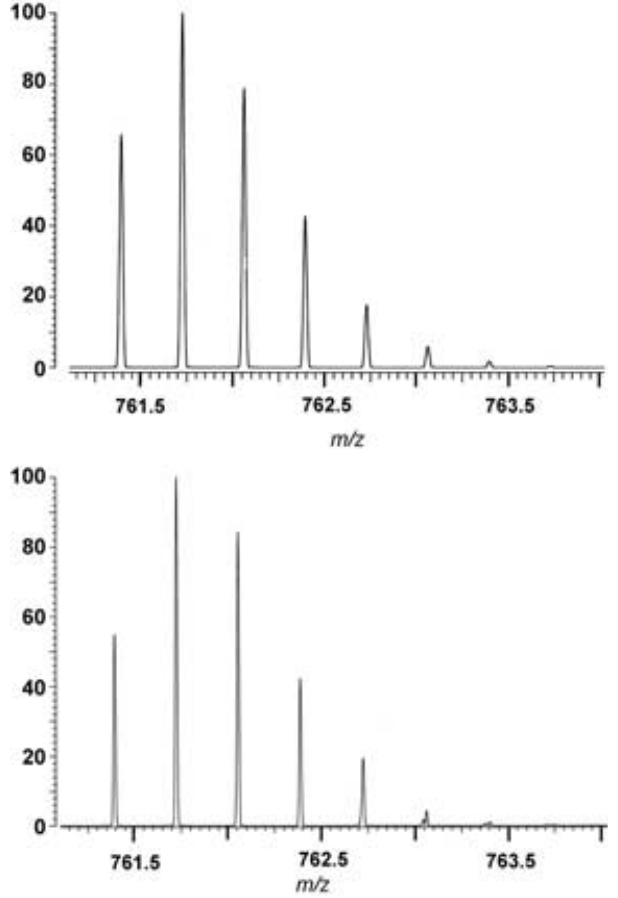

Figure 6. High resolution mass spectrum of the $[4]$ rotaxane $\left[\mathbf{1 2}-\mathrm{H}_{3}\right]\left[\mathrm{PF}_{6}\right]_{3}$. The experimental isotopic distribution (lower trace) corresponds to $\left[M-3 \mathrm{PF}_{6}\right]^{+}$and it matches the calculated one (upper trace) having $0.33 \mathrm{~m} / \mathrm{z}$ differences caused by the triple charge on the species.
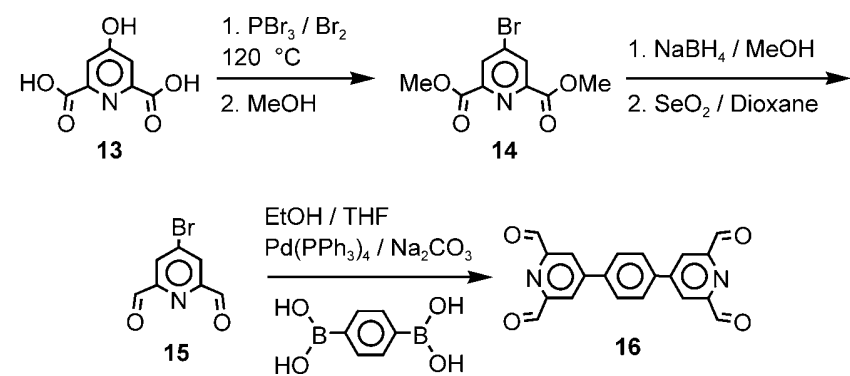

Scheme 6. Synthesis of the tetraaldehyde $\mathbf{1 6}$.

tion, its terphenylene-based structure brings with it solubility problems. The compound is slightly soluble in pyridine, nitrobenzene, and nitromethane, and only sparingly soluble in acetonitrile and toluene. A ${ }^{1} \mathrm{H}$ NMR spectrum of $\mathbf{1 6}$ recorded in $\mathrm{C}_{6} \mathrm{D}_{5} \mathrm{NO}_{2}$ reveals three extremely weak signals relative to the intense resonances corresponding to the residual solvent. The tetraaldehyde is virtually insoluble in all the other solvents, including $\mathrm{Me}_{2} \mathrm{SO}$. Nonetheless, clipping reactions involving 16, 2, and the dumbbell template $[3-\mathrm{H}] \mathrm{PF}_{6}$ gave very encouraging results (Scheme 7). Since $\mathbf{1 6}$ is only partially soluble in $\mathrm{CD}_{3} \mathrm{NO}_{2}$, the clipping reaction was initiated by heating a suspension containing all three components for a few seconds with a heat gun. After heating and

cycles by linking two 2,6-pyridinedicarboxaldehyde units together and reacting the subsequent tetraaldehyde with bisammonium salts, such as $\left[\mathbf{9}-\mathrm{H}_{2}\right]-$ $\left[\mathrm{PF}_{6}\right]_{2}$.

The synthesis of the tetraaldehyde 16, which was selected for this particular investigation, was carried out as shown in Scheme 6 following a procedure similar to that reported by Hosseini et al. ${ }^{[35]}$ for the synthesis of a bis-tridentate ligand based on a combination of two pyridine and four thioether

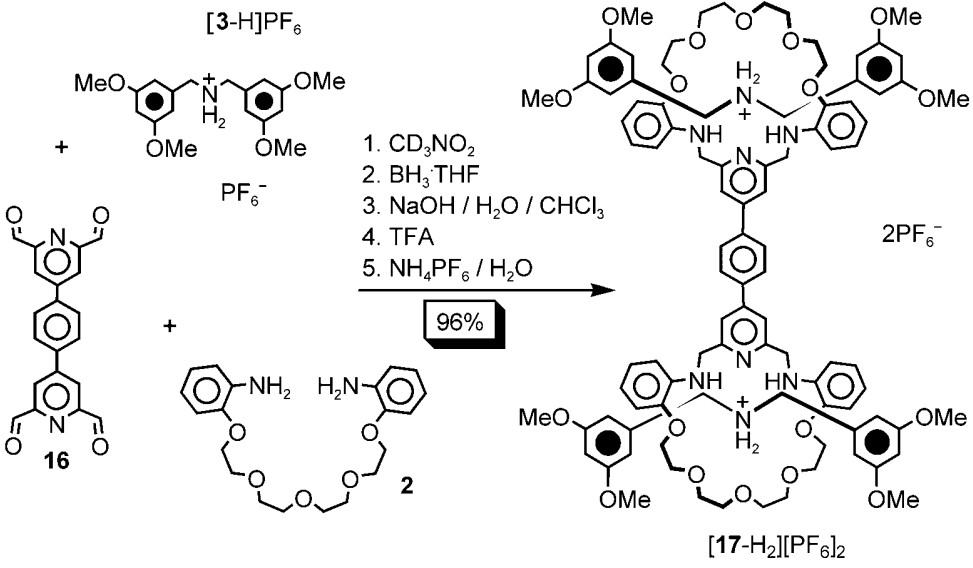

Scheme 7. Synthesis of the bis[2]rotaxane $\left[\mathbf{1 7}-\mathrm{H}_{2}\right]\left[\mathrm{PF}_{6}\right]_{2}$. groups. Phosphorus pentabro-

mide was generated in situ from phosphorous tribromide and bromine. The resulting yellow solid was added to chelidemic acid (13), and the two solids were heated to $120^{\circ} \mathrm{C}$ with thorough mixing. The reaction was quenched by the addition of $\mathrm{MeOH}$ to convert the acid bromide into the corresponding methyl ester 14. The ester functions were reduced $\left(\mathrm{NaBH}_{4}\right)$ and the resulting diol was oxidized using $\mathrm{SeO}_{2}$ to afford the dialdehyde 15. Coupling two of these dialdehydes by using a modified Suzuki reaction and $p$-phenylenebisboronic acid gave the tetraaldehyde $\mathbf{1 6}$ in good yield.

Even although the tetraaldehyde $\mathbf{1 6}$ was easily accessible synthetically by using a high-yielding Suzuki coupling reac- sonication, the solution became bright yellow and no solid residue remained in the flask. The resulting ${ }^{1} \mathrm{H}$ NMR spectrum (Figure 7) indicates that the dynamic bis[2]rotaxane is formed in almost quantitative yield: in particular, the appearance of a sharp imine proton resonance $(\delta=8.27 \mathrm{ppm})$ is accompanied by the disappearance of the aldehyde proton signal at $\delta=10.14 \mathrm{ppm}$. Finally, reduction of the dynamic bis[2]rotaxane led to the isolation of the kinetically stable bis[2]rotaxane $\left[\mathbf{1 7}-\mathrm{H}_{2}\right]\left[\mathrm{PF}_{6}\right]_{2}$ in a remarkable $96 \%$ yield. High-resolution electrospray mass spectrometry and NMR spectroscopy confirmed the structural identity of this compound. 


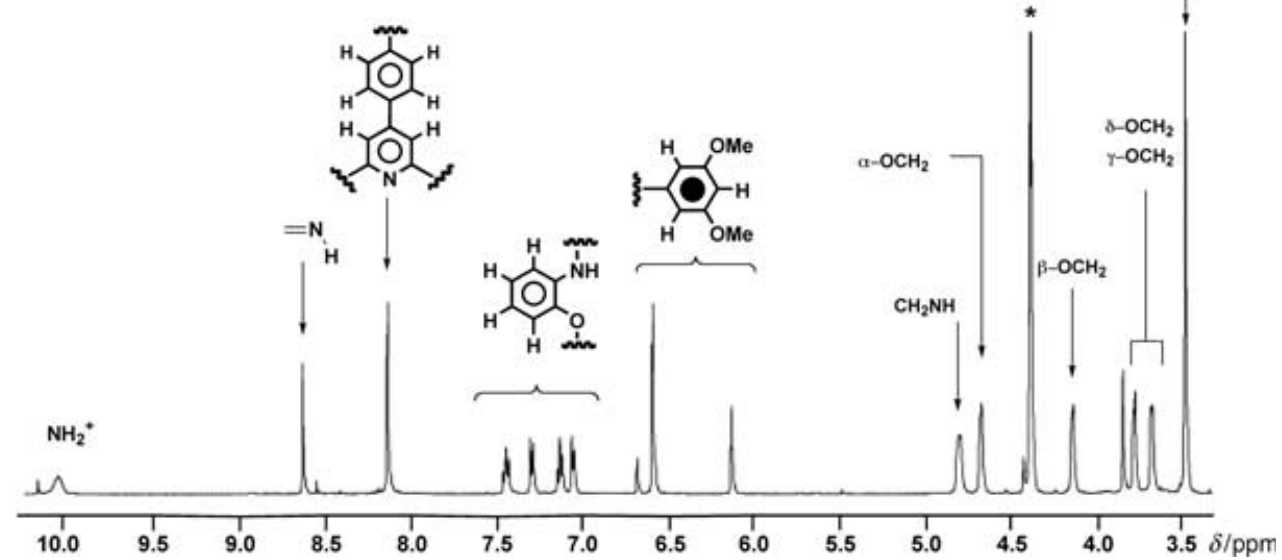

Figure 7. Partial ${ }^{1} \mathrm{H}$ NMR spectrum $(500 \mathrm{MHz})$ of the dynamic bis[2]rotaxane prior to the reduction of the imine bonds $\left(\alpha, \beta, \gamma, \delta\right.$-OCH ${ }_{2}$ correspond to the protons of the ethylene glycol chain as labeled in Scheme 3).

Slow evaporation of a solution of the bis[2]rotaxane [17$\left.\mathrm{H}_{2}\right]\left[\mathrm{PF}_{6}\right]_{2}$ in $\mathrm{CH}_{2} \mathrm{Cl}_{2} / \mathrm{EtOH}$ yielded single crystals suitable for X-ray structural analysis. Its solid-state structure is shown in Figure 8. The structure has a crystallographic in-

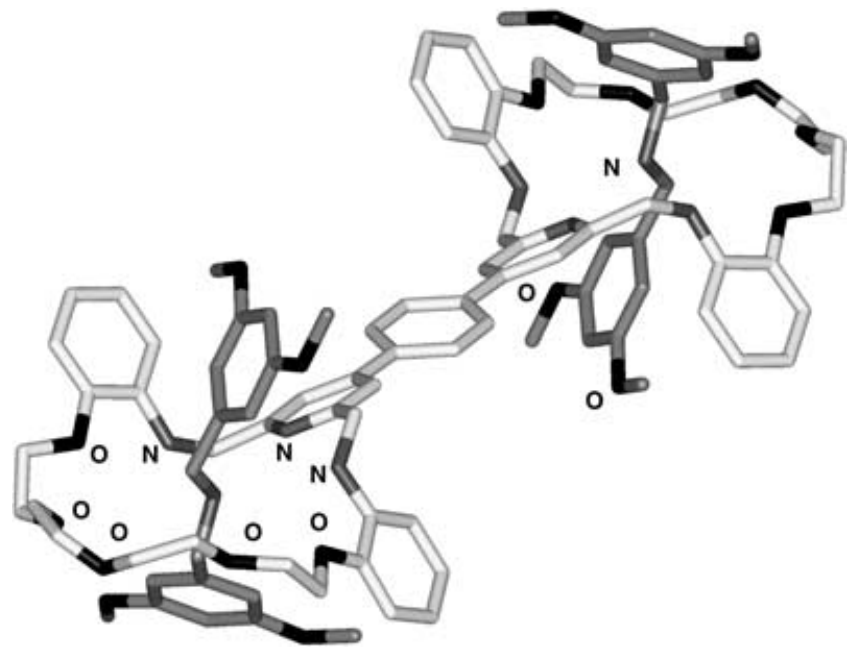

Figure 8 . Solid-state structure of the bis[2]rotaxane $\left[\mathbf{1 7}-\mathrm{H}_{2}\right]\left[\mathrm{PF}_{6}\right]_{2}$.

version center at the middle of the phenylene ring connecting the two halves of the bis[2]rotaxane. The centrosymmetric phenylene ring is disordered between two orientations (rotated about $37^{\circ}$ along the axis) in an 80:20 ratio. A similar disorded distribution of the two orientations is also present around one of the oxygen atoms of the macrocycles. The dicationic dumbbell-shaped component is threaded through the central cavity of the crown ether and the resulting coconformation is stabilized by $\mathrm{N}^{+}-\mathrm{H} \cdots \mathrm{N}$ hydrogen bonds and $\mathrm{C}-\mathrm{H} \cdots \mathrm{O}$ interactions. The $\mathrm{N}^{+}-\mathrm{H} \cdots \mathrm{N}$ hydrogen bonds are between the $\mathrm{NH}_{2}{ }^{+}$centers on the dumbbell-shaped component and the aminophenol-derived nitrogen atoms. The $\mathrm{C}^{-}$
$\mathrm{H} \cdots \mathrm{O}$ interactions are between both $\mathrm{CH}_{2}$ groups in the dumbbell-shaped component and two of the oxygen atoms in the macrocycles. These interactions are further supplemented by $\mathrm{C}-\mathrm{H} \cdots \pi$ bonds between the 3,5-dimethoxyphenyl rings of the dumbbell and the two $\mathrm{CH}_{2}$ groups adjacent to the aminophenol in the ring component.

These results have encouraged us to try and assemble a yet more exotic mechanically interlocked molecular structure in which eight components cooperate to form a jumbosized cycle $\left[\mathbf{1 8}-\mathrm{H}_{4}\right]\left[\mathrm{PF}_{6}\right]_{4}$ (Scheme 8) The tetraaldehyde 16 ( 2 equiv), the bis-aniline 2 (4 equiv) and the secondary dialkylammonium salt $\left[\mathbf{9}-\mathrm{H}_{2}\right]\left[\mathrm{PF}_{6}\right]_{2}$ were mixed together in $\mathrm{CD}_{3} \mathrm{NO}_{2}$. As in the previous case, the clipping reaction needs to be initiated by heating the suspension containing the components. As a consequence of the nature of the precursors, polymeric materials or non-templated products could easily be the outcome. The ${ }^{1} \mathrm{H}$ NMR spectrum (Figure 9) showed, however, no evidence for the presence of other compounds; only the dynamic mechanically interlocked compound is observed. All the proton signals can be assigned easily within the context of a dynamic jumbo-sized cycle. Reduction of the imine bonds by $\mathrm{BH}_{3}$. THF resulted in the isolation of the kinetically stable interlocked compound $\left[\mathbf{1 8}-\mathrm{H}_{4}\right]\left[\mathrm{PF}_{6}\right]_{4}$. The crude product could be further purified by recrystallization from EtOH to achieve a very pure sample of the branched [4]rotaxane. A portion of the ${ }^{1} \mathrm{H}$ NMR spectrum of the kinetically stable product is shown in Figure 9. High-resolution electrospray mass spectrometry confirmed the proposed constitution of the mechanically interlocked compound.

\section{Conclusion}

Simple and efficient syntheses are the key to taking a piece of chemistry from being just a curiosity to being something more substantial. The importance of the research described 


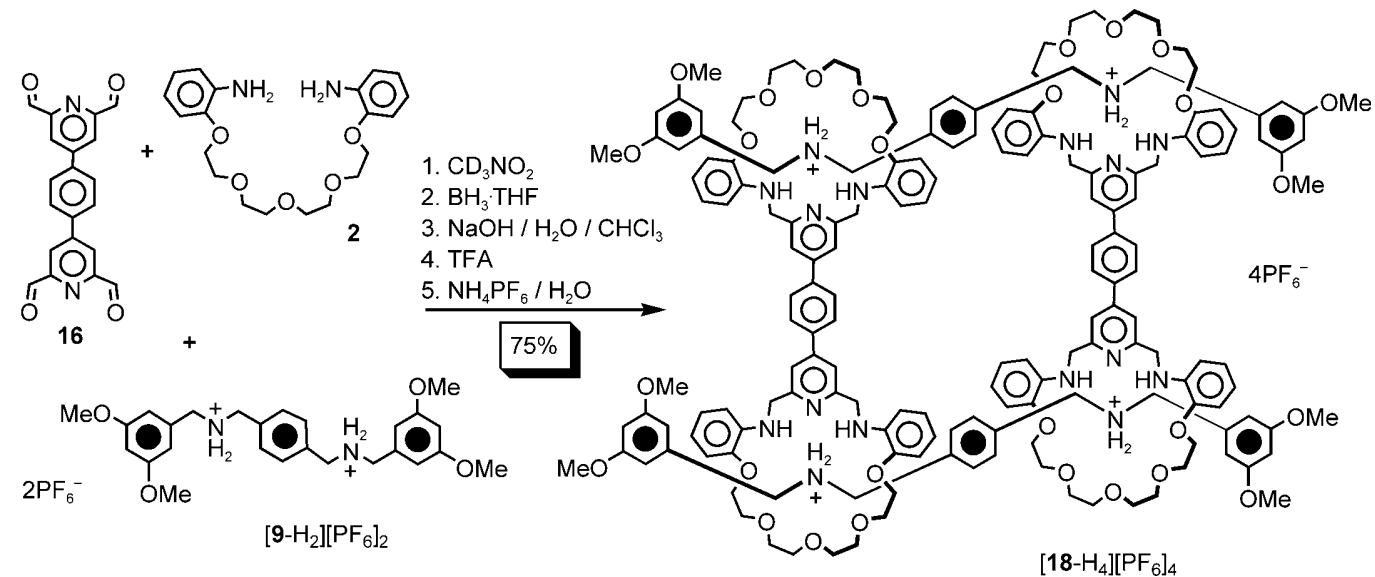

Scheme 8. Synthesis of the $[4]$ rotaxane $\left[18-\mathrm{H}_{4}\right]\left[\mathrm{PF}_{6}\right]_{4}$.

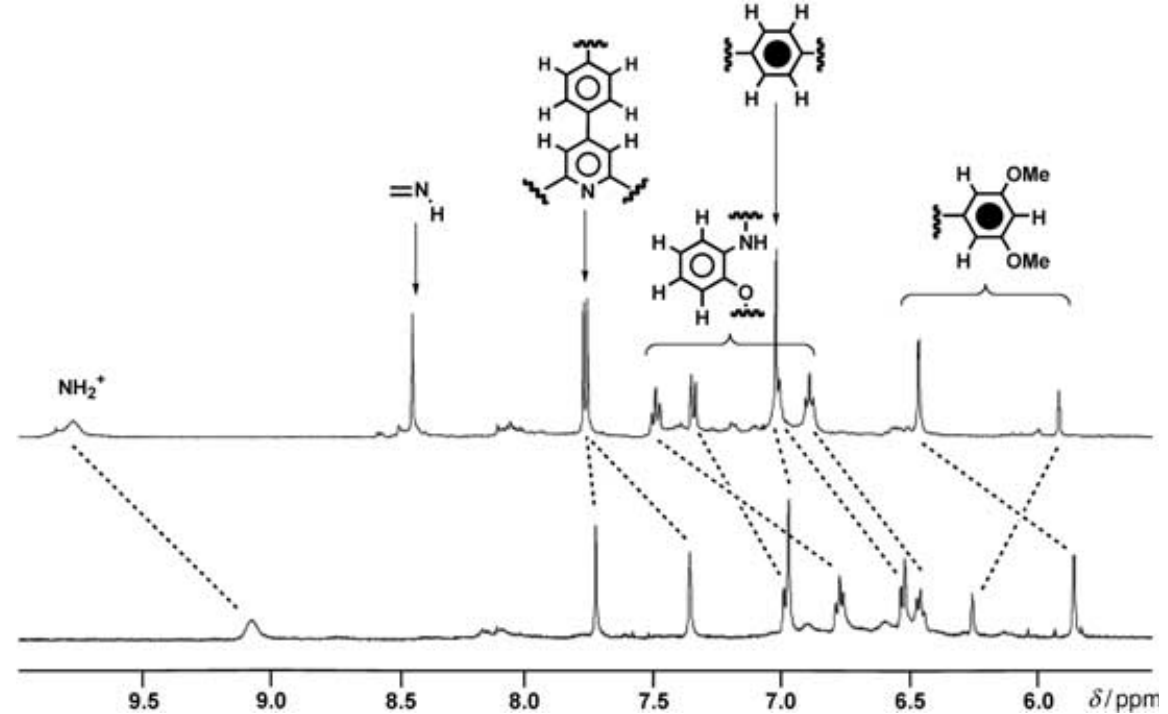

Figure 9. Partial ${ }^{1} \mathrm{H}$ NMR spectra $\left(500 \mathrm{MHz}, \mathrm{CD}_{3} \mathrm{NO}_{2}\right)$ of the dynamic cyclic [4]rotaxane formation (upper trace) and of its related kinetically stable cyclic [4]rotaxane $\left[\mathbf{1 8}-\mathrm{H}_{4}\right]\left[\mathrm{PF}_{6}\right]_{4}$ (lower trace) after reduction of the imine bonds.

in this full paper rests very much on this premise. We have found that, by using supramolecular assistance-which relies upon $\mathrm{N}^{+}-\mathrm{H} \cdots \mathrm{O}$ and $\mathrm{N}^{+}-\mathrm{H} \cdots \mathrm{N}$ hydrogen bonds and $\mathrm{C}^{-}$ $\mathrm{H} \cdots \mathrm{O}, \mathrm{C}-\mathrm{H} \cdots \mathrm{N}$, and $\pi \cdots \pi$ stacking interactions - to reversible imine bond formation, the mechanical bond can be incorporated quickly and near-quantitatively at numerous different sites in mechanically interlocked molecules under thermodynamic control. The further discovery that $\mathrm{BH}_{3} \cdot \mathrm{THF}$ can be employed to carry out repeated reductive aminations with speed and accuracy overall represents yet another advance on the previous available methodologies. It seems likely that the $\mathrm{NH}_{2}{ }^{+}$centers, which act as templates for the production of the macrocycles with their two imine bonds, also activate imine bond formation, that is, the stereoelectronics associated with the whole process are good if not excellent. Last, but by no means least, the products with two secondary amine functions in their ring components can be isolated by a bulk extraction procedure without us having to resort to the use of chromatography. We have a way of making multiply mechanically interlocked molecular compounds on a gram scale.

\section{Experimental Section}

General methods: Reagents were purchased from Aldrich or synthesized as described in the literature. 2,6-Pyridinedicarboxaldehyde (1), tetraethyleneglycol bis(2-aminophenyl) ether ${ }^{[28]}$ (2), bis-3,5-dimethoxybenzylammonium hexafluorophosphate $e^{[28]}([3-\mathrm{H}]-$ $\mathrm{PF}_{6}$ ), the trifurcated trisammonium salt ${ }^{[23]}\left[11-\mathrm{H}_{3}\right]\left[\mathrm{PF}_{6}\right]_{3}$ and 4-bromo-2,6pyridinedicarboxyaldehyde ${ }^{[36]}$ were all prepared according to literature procedures. Solvents were purified according to literature procedures. ${ }^{[37]}$ Thin-layer chromatography (TLC) was carried out using aluminum sheets, precoated with silica gel 60F (Merck 5554). The plates were inspected by UV light, prior to their development with iodine vapor. Melting points were determined on an Electrothermal 9200 apparatus and are uncorrected. Proton and carbon nuclear magnetic resonance spectra $\left({ }^{1} \mathrm{H} \mathrm{NMR}\right.$ and $\left.{ }^{13} \mathrm{C} \mathrm{NMR}\right)$ spectra were recorded on Bruker Avance 500 or ARX 500 spectrometers, using the deuterated solvent as lock and the residual protonated solvent as internal standard. All chemical shifts are quoted using the $\delta$ scale, and all coupling constants $(J)$ are expressed in Hertz $(\mathrm{Hz})$. Electrospray mass spectra (ESI-MS) were measured on a VG ProSpec triple focusing mass spectrometer.

[2]Rotaxane [5-H]PF $\mathbf{P F}_{\mathbf{6}}$ : A solution of $\mathbf{1}(10 \mathrm{mg}, 0.074 \mathrm{mmol}), \mathbf{2}(27.9 \mathrm{mg}$, $0.074 \mathrm{mmol})$, and $[3-\mathrm{H}] \mathrm{PF}_{6}(34.3 \mathrm{mg}, 0.074 \mathrm{mmol})$ in $\mathrm{CD}_{3} \mathrm{NO}_{2}(1.5 \mathrm{~mL})$ was stirred at room temperature for $5 \mathrm{~min}$. A solution of $1.8 \mathrm{M} \mathrm{BH}$ in THF $(170 \mu \mathrm{L}, 0.306 \mathrm{mmol})$ was added to the mixture and it was allowed to stir at room temperature for further $2 \mathrm{~h}$. The solvent was then evaporated off and the residue was distributed between $2 \mathrm{~m}$ aqueous $\mathrm{NaOH}$ solution and $\mathrm{CHCl}_{3}$. The organic extracts were dried $\left(\mathrm{MgSO}_{4}\right)$ and the solvent was evaporated. The residue was dissolved in $\mathrm{Me}_{2} \mathrm{CO}$ 
and TFA (few drops) was added to the solution. After evaporation of the solvent, the residual oil was dissolved in a mixture of $\mathrm{H}_{2} \mathrm{O}$ and $\mathrm{Me}_{2} \mathrm{CO}$ and saturated aqueous solution of $\mathrm{NH}_{4} \mathrm{PF}_{6}$ was added. The $\mathrm{Me}_{2} \mathrm{CO}$ was then removed and the aqueous solution was extracted with $\mathrm{CH}_{2} \mathrm{Cl}_{2}$ several times. The organic extracts were dried $\left(\mathrm{MgSO}_{4}\right)$ and the solvent was evaporated to dryness to yield the [2] rotaxane $[\mathbf{5}-\mathrm{H}] \mathrm{PF}_{6}$ as a white powder $(60 \mathrm{mg}, 86 \%)$. Characterization of this compound is consistent with that reported in the literature. ${ }^{[28]}$

Macrocycle 8: A solution of $\mathbf{1}(40 \mathrm{mg}, 0.29 \mathrm{mmol}), \quad 2 \quad(110 \mathrm{mg}$, $0.29 \mathrm{mmol})$, and $\left[7-\mathrm{H} \mathrm{PF}_{6}(100 \mathrm{mg}, 0.29 \mathrm{mmol})\right.$ in $\mathrm{MeNO}_{2}(5 \mathrm{~mL})$ was stirred at room temperature for $5 \mathrm{~min}$. $\mathrm{BH}_{3}$. THF $(1.8 \mathrm{M}$ in THF, $0.6 \mathrm{~mL}$, $1.08 \mathrm{mmol}$ ) was added to the mixture, which was left stirring at room temperature for $2 \mathrm{~h}$. The solvent was then evaporated off and the residue was partitioned between $2 \mathrm{M}$ aqueous $\mathrm{NaOH}$ solution and $\mathrm{CHCl}_{3}$. The organic extracts were dried $\left(\mathrm{MgSO}_{4}\right)$ and the solvent was evaporated again. The residue was dissolved in warm $\mathrm{MeOH}$ and filtered to recover the macrocycle $\mathbf{8}(115 \mathrm{mg}, 80 \%)$ as a white crystalline powder. M.p. 143 $144^{\circ} \mathrm{C} ;{ }^{1} \mathrm{H}$ NMR $\left(\mathrm{CDCl}_{3}, 500 \mathrm{MHz}, 298 \mathrm{~K}\right): \delta=3.60-3.62(\mathrm{~m}, 4 \mathrm{H}), 3.78$ $3.79(\mathrm{~m}, 4 \mathrm{H}), 3.88-3.89(\mathrm{~m}, 4 \mathrm{H}), 4.20-4.21(\mathrm{~m}, 4 \mathrm{H}), 4.56(\mathrm{~d}, J=5 \mathrm{~Hz}$, $4 \mathrm{H}), 5.84(\mathrm{brs}, 2 \mathrm{H}), 6.66-6.71(\mathrm{~m}, 4 \mathrm{H}), 6.91(\mathrm{~d}, J=7.7 \mathrm{~Hz}, 2 \mathrm{H}), 6.96(\mathrm{t}$, $J=7.7 \mathrm{~Hz}, 2 \mathrm{H}) 7.25(\mathrm{~d}, J=7.7 \mathrm{~Hz}, 2 \mathrm{H}), 7.63 \mathrm{ppm}(\mathrm{t}, J=7.7 \mathrm{~Hz}, 1 \mathrm{H})$; ${ }^{13} \mathrm{C} \mathrm{NMR}\left(\mathrm{CDCl}_{3}, 125 \mathrm{MHz}, 298 \mathrm{~K}\right): \delta=48.9,68.9,70.2,70.6,70.7,110.3$, 114.2, 116.2, 119.6, 122.8, 136.9, 139.9, $146.0158 .2 \mathrm{ppm}$; HRMS (EI): $\mathrm{m} / \mathrm{z}$ calcd for $\mathrm{C}_{27} \mathrm{H}_{33} \mathrm{~N}_{3} \mathrm{O}_{5}$ : 479.2420; found: 479.2413. Slow evaporation of a solution of $\mathbf{8}$ in $\mathrm{CHCl}_{3}$ and hexane yielded a single crystal suitable for $\mathrm{X}$ ray crystallography.

Bisammonium salt $\left[\mathbf{9}-\mathbf{H}_{2}\right]\left[\mathbf{P F}_{\mathbf{6}}\right]_{2}$ : A solution of $p$-xylylenediamine $(1.00 \mathrm{~g}$, $7.34 \mathrm{mmol})$ and 3,5-dimethoxybenzaldehyde $(2.44 \mathrm{~g}, 14.68 \mathrm{mmol})$ in PhMe $(120 \mathrm{~mL})$ was heated under reflux for $20 \mathrm{~h}$ using a Dean-Stark apparatus. The resulting solution was evaporated to dryness, the residue dissolved in $\mathrm{MeOH}(250 \mathrm{~mL})$, and $\mathrm{NaBH}_{4}(1.85 \mathrm{~g}, 50 \mathrm{mmol})$ was added portionwise during $10 \mathrm{~min}$. After stirring the reaction mixture under ambient conditions for $12 \mathrm{~h}$, the solvents were removed in vacuo, and the residue was partitioned between $\mathrm{H}_{2} \mathrm{O}$ and $\mathrm{CH}_{2} \mathrm{Cl}_{2}(250 \mathrm{~mL})$. The aqueous layer was further extracted with $\mathrm{CH}_{2} \mathrm{Cl}_{2}(3 \times 250 \mathrm{~mL})$, the combined organic extracts were dried $\left(\mathrm{MgSO}_{4}\right)$, and the resulting solution was evaporated to dryness to yield a colorless oil. The oil was subsequently dissolved in $\mathrm{MeOH}(200 \mathrm{~mL})$, and TFA $(10 \mathrm{~mL})$ was added carefully. After stirring for about $10 \mathrm{~min}$, the solvents were removed in vacuo to give a white solid, which was then dissolved in a mixture of $\mathrm{H}_{2} \mathrm{O}$ and $\mathrm{Me}_{2} \mathrm{CO}$. Addition of an excess of saturated aqueous $\mathrm{NH}_{4} \mathrm{PF}_{6}$ to this solution resulted in the precipitation of the desired compound, which was collected and dried to give $\left[9-\mathrm{H}_{2}\right]\left[\mathrm{PF}_{6}\right]_{2}(3.6 \mathrm{~g}, 70 \%)$ as a white solid. M.p. $224-225^{\circ} \mathrm{C}$; ${ }^{1} \mathrm{H}$ NMR $\left(500 \mathrm{MHz}, \mathrm{CD}_{3} \mathrm{COCD}_{3}\right): \delta=3.76(\mathrm{~s}, 12 \mathrm{H}), 4.51(\mathrm{~s}, 4 \mathrm{H}), 4.63$ (s, $4 \mathrm{H}) 6.54(\mathrm{t}, J=2.1 \mathrm{~Hz}, 2 \mathrm{H}), 6.70(\mathrm{~d}, J=2.1 \mathrm{~Hz}, 4 \mathrm{H}), 7.68 \mathrm{ppm}(\mathrm{s}, 4 \mathrm{H})$; ${ }^{13} \mathrm{C} \mathrm{NMR}\left(\mathrm{CD}_{3} \mathrm{COCD}_{3}, 125 \mathrm{MHz}, 298 \mathrm{~K}\right): \delta=51.0,51.7,54.8,99.9,107.7$, 130.7, 132.4, 132.7, $161.3 \mathrm{ppm}$; HRMS (ESI): $\mathrm{m} / \mathrm{z}$ calcd for $\mathrm{C}_{26} \mathrm{H}_{34} \mathrm{~F}_{12} \mathrm{~N}_{2} \mathrm{O}_{4} \mathrm{P}_{2}\left[M-2 \mathrm{PF}_{6}\right]^{2+}$ : 437.2434; found: 427.2453 .

[3]Rotaxane [10-- $\left.\mathbf{H}_{2}\right]\left[\mathbf{P F}_{\mathbf{6}}\right]_{2}:$ A solution of $\mathbf{1}(14.5 \mathrm{mg}, 0.1 \mathrm{mmol}), \mathbf{2}$ $(40 \mathrm{mg}, 0.1 \mathrm{mmol})$ and the bisammonium salt $\left[9-\mathrm{H}_{2}\right]\left[\mathrm{PF}_{6}\right]_{2} \quad(38.7 \mathrm{mg}$, $0.05 \mathrm{mmol})$ in $\mathrm{CD}_{3} \mathrm{NO}_{2}(3 \mathrm{~mL})$ was stirred at room temperature for $5 \mathrm{~min} . \mathrm{BH}_{3} \cdot \mathrm{THF}(1.8 \mathrm{M}$ in THF, $300 \mu \mathrm{l}, 0.540 \mathrm{mmol})$ was added to the mixture, which was left stirring at room temperature for $4 \mathrm{~h}$. The solvent was then evaporated off and the residue was partitioned between $2 \mathrm{M}$ aqueous $\mathrm{NaOH}$ and $\mathrm{CHCl}_{3}$. The organic extracts were dried and the solvent evaporated again. The residue was dissolved in $\mathrm{Me}_{2} \mathrm{CO}$, and few drops of TFA were added to the solution. The solvent was evaporated off, the residual oil was dissolved in a mixture of $\mathrm{H}_{2} \mathrm{O}$ and $\mathrm{Me}_{2} \mathrm{CO}$, and a saturated aqueous solution of $\mathrm{NH}_{4} \mathrm{PF}_{6}$ was added. The $\mathrm{Me}_{2} \mathrm{CO}$ was then removed and the aqueous solution was extracted with $\mathrm{CH}_{2} \mathrm{Cl}_{2}$ several times. The organic extracts were dried $\left(\mathrm{MgSO}_{4}\right)$ and concentrated to dryness to yield the [3] rotaxane $\left[\mathbf{1 0}-\mathrm{H}_{2}\right]\left[\mathrm{PF}_{6}\right]_{2}(71 \mathrm{mg}, 80 \%)$ as a white powder. M.p. $160-162{ }^{\circ} \mathrm{C} ;{ }^{1} \mathrm{H} \mathrm{NMR}\left(\mathrm{CD}_{3} \mathrm{COCD}_{3}, 500 \mathrm{MHz}, 298 \mathrm{~K}\right): \delta=$ $3.47(\mathrm{~s}, 12 \mathrm{H}), 3.68-4.10(\mathrm{~m}, 32 \mathrm{H}), 4.19(\mathrm{brs}, 8 \mathrm{H}), 4.62(\mathrm{brs}, 8 \mathrm{H}), 6.24-$ $6.26(\mathrm{~m}, 4 \mathrm{H}), 6.38-6.39(\mathrm{~m}, 2 \mathrm{H}), 6.47(\mathrm{~d}, J=7.5 \mathrm{~Hz}, 4 \mathrm{H}), 6.54(\mathrm{~s}, 4 \mathrm{H})$, 6.66-6.75 (m, 12H), $7.56(\mathrm{~d}, J=7.5 \mathrm{~Hz}, 4 \mathrm{H}), 7.96(\mathrm{t}, J=7.5 \mathrm{~Hz}, 2 \mathrm{H})$, $8.97 \mathrm{ppm}(\mathrm{brs}, 4 \mathrm{H}) ;{ }^{13} \mathrm{C} \mathrm{NMR}\left(\mathrm{CD}_{3} \mathrm{COCD}_{3}, 125 \mathrm{MHz}, 298 \mathrm{~K}\right): \delta=49.8$, 54.6, 67.4, 70.3, 71.0, 71.4, 100.8, 106.7, 109.9, 112.5, 119.7, 121.0, 122.0
128.9, 146.7, $161.0 \mathrm{ppm}$; HRMS (ESI): $\mathrm{m} / z$ calcd for $\mathrm{C}_{80} \mathrm{H}_{100} \mathrm{~F}_{12} \mathrm{~N}_{8} \mathrm{O}_{14} \mathrm{P}_{2}$ $\left[M-\mathrm{PF}_{6}\right]^{+}:$1541.6995; found: 1541.7012. Single crystals, suitable for $\mathrm{X}$ ray crystallography, were grown by liquid diffusion of EtOH into a solution of $\left[\mathbf{1 0}-\mathrm{H}_{2}\right]\left[\mathrm{PF}_{6}\right]_{2}$ in $\mathrm{CHCl}_{3}$.

[4]Rotaxane $\left[\mathbf{1 2}_{-}-\mathbf{H}_{3}\right]\left[\mathbf{P F}_{6}\right]_{3}:$ A solution of $\mathbf{1}(9.5 \mathrm{mg}, 0.07 \mathrm{mmol}), \mathbf{2}$ $(26.5 \mathrm{mg}, 0.07 \mathrm{mmol})$, and the trifurcated trisammonium salt $\left[\mathbf{1 1}-\mathrm{H}_{3}\right]\left[\mathrm{PF}_{6}\right]_{3}$ (30 mg, $0.023 \mathrm{mmol})$ in $\mathrm{CD}_{3} \mathrm{NO}_{2}(2 \mathrm{~mL})$ was stirred at room temperature for $5 \mathrm{~min}$. $\mathrm{BH}_{3}$ THF ( $1.8 \mathrm{M}$ in THF, $\left.90 \mu \mathrm{l}, 0.162 \mathrm{mmol}\right)$ was added to the mixture, and the resulting solution was allowed to stir at room temperature overnight. The solvent was then evaporated off, and the residue was partitioned between $2 \mathrm{M}$ aqueous $\mathrm{NaOH}$ and $\mathrm{CHCl}_{3}$. The organic extracts were dried and concentrated to give a solid, which was dissolved in $\mathrm{Me}_{2} \mathrm{CO}$ and few drops of TFA were added to the solution. The solvent was evaporated off, the residual oil was dissolved in a mixture of $\mathrm{H}_{2} \mathrm{O}$ and $\mathrm{MeOH}$, and a saturated aqueous solution of $\mathrm{NH}_{4} \mathrm{PF}_{6}$ was added. The $\mathrm{MeOH}$ was then removed, and the aqueous solution was extracted with $\mathrm{CH}_{2} \mathrm{Cl}_{2}$ several times. The organic extracts were dried $\left(\mathrm{MgSO}_{4}\right)$ and the solvent was evaporated to dryness to yield the [4]rotaxane $\left[\mathbf{1 2}-\mathrm{H}_{3}\right]\left[\mathrm{PF}_{6}\right]_{3}$ $(55 \mathrm{mg}, 87 \%)$ as a yellow powder. M.p. $130-131{ }^{\circ} \mathrm{C} ;{ }^{1} \mathrm{H} \mathrm{NMR}$ $\left(\mathrm{CD}_{3} \mathrm{COCD}_{3}, 500 \mathrm{MHz}, 298 \mathrm{~K}\right): \delta=3.41(\mathrm{~s}, 18 \mathrm{H}), 3.79-4.05(\mathrm{~m}, 16 \mathrm{H})$, $4.12-4.22(\mathrm{~m}, 48 \mathrm{H}), 4.10-4.20(\mathrm{~m}, 12 \mathrm{H}), 4.70-4.80(\mathrm{~m}, 12 \mathrm{H}), 6.23(\mathrm{~d}, J=$ $1.8 \mathrm{~Hz}, 6 \mathrm{H}), 6.33-6.34(\mathrm{~m}, J=1.9,3 \mathrm{H}), 6.45(\mathrm{~d}, J=7.6 \mathrm{~Hz}, 6 \mathrm{H}), 6.59-6.70$ $(\mathrm{m}, 18 \mathrm{H}) 7.11(\mathrm{~d}, J=7.8 \mathrm{~Hz}, 6 \mathrm{H}), 7.40(\mathrm{~d}, J=8.0 \mathrm{~Hz}, 6 \mathrm{H}), 7.49(\mathrm{~d}, J=$ $7.6 \mathrm{~Hz}, 6 \mathrm{H}), 7.66(\mathrm{~s}, 3 \mathrm{H}), 7.86(\mathrm{t}, 7.5 \mathrm{~Hz}, 3 \mathrm{H}), 9.03 \mathrm{ppm}(\mathrm{brs}, 6 \mathrm{H})$; ${ }^{13} \mathrm{C}$ NMR $\left(\mathrm{CD}_{3} \mathrm{COCD}_{3}, 125 \mathrm{MHz}, 298 \mathrm{~K}\right): \delta=49.6,52.4,54.7,67.3,70.3$, 71.0, 71.3, 100.8, 106.6, 110.0, 112.3, 119.4, 121.0, 122.0, 124.7, 127.2, 129.3 137.0, 138.2, 140.6, 141.2, 146.8, 158.9, $161.1 \mathrm{ppm}$; HRMS (ESI): $\mathrm{m} / \mathrm{z}$ calcd for $\mathrm{C}_{135} \mathrm{H}_{159} \mathrm{~F}_{18} \mathrm{~N}_{12} \mathrm{O}_{21} \mathrm{P}_{3}\left[M-3 \mathrm{PF}_{6}\right]^{+}$: 761.3921; found: 761.3908 .

Tetraaldehyde 16: $\mathrm{Pd}\left(\mathrm{PPh}_{3}\right)_{4}(0.50 \mathrm{~g}, 0.31 \mathrm{mmol})$ was added to a degassed solution of 2,6-diformyl-4-bromopyridine $(1.50 \mathrm{~g}, 7.01 \mathrm{mmol})$ in THF $(80 \mathrm{~mL})$. A degassed solution of $\mathrm{Na}_{2} \mathrm{CO}_{3}(20 \%$ aq) and $p$-phenylbisboronic acid $(0.58 \mathrm{~g}, 3.51 \mathrm{mmol})$ in EtOH $(10 \mathrm{~mL})$ was injected into the solution. The resulting mixture was heated at $80^{\circ} \mathrm{C}$ for 2 days. After cooling down to room temperature, the solvent was evaporated and the residue was filtered and washed with $\mathrm{Me}_{2} \mathrm{SO}, \mathrm{H}_{2} \mathrm{O}, \mathrm{Me}_{2} \mathrm{CO}$, and hexanes to give the tetraaldehyde $\mathbf{1 6}(1.0 \mathrm{~g}, 80 \%)$ as a white powder. ${ }^{1} \mathrm{H}$ NMR $\left(400 \mathrm{MHz}, \mathrm{CD}_{3} \mathrm{NO}_{2}\right): \delta=7.86(\mathrm{~s}, 4 \mathrm{H}), 8.34(\mathrm{~s}, 4 \mathrm{H}), 10.16 \mathrm{ppm}(\mathrm{s}, 4 \mathrm{H})$.

Bis[2]rotaxane [17- $\left.\mathbf{H}_{2}\right]\left[\mathbf{P F}_{\mathbf{6}}\right]_{2}:$ A solution of the tetraaldehyde $\mathbf{1 6}(30 \mathrm{mg}$, $0.087 \mathrm{mmol}), 2$ (66 mg, $0.174 \mathrm{mmol})$, and [3-H]PF 6 (80.7 mg, $0.174 \mathrm{mmol})$ in $\mathrm{CD}_{3} \mathrm{NO}_{2}(6 \mathrm{~mL})$ was stirred at room temperature for $5 \mathrm{~min}$. $\mathrm{BH}_{3} \cdot \mathrm{THF}$ $(1.8 \mathrm{M}$ in THF, $260 \mu \mathrm{l}, 0.468 \mathrm{mmol}$ ) was added to the mixture, which was stirred at room temperature overnight. The solvent was then evaporated off, and the residue was partitioned between $2 \mathrm{~m}$ aqueous $\mathrm{NaOH}$ and $\mathrm{CHCl}_{3}$. The organic extracts were dried and the solvent removed. The residue was dissolved in $\mathrm{Me}_{2} \mathrm{CO}$ and few drops of TFA were added to the solution. The solvent was evaporated off, the oily residue was dissolved in a mixture of $\mathrm{H}_{2} \mathrm{O}$ and $\mathrm{Me}_{2} \mathrm{CO}$, and a saturated aqueous solution of $\mathrm{NH}_{4} \mathrm{PF}_{6}$ was added. The $\mathrm{Me}_{2} \mathrm{CO}$ was then removed and the aqueous solution was extracted with $\mathrm{CH}_{2} \mathrm{Cl}_{2}$ several times. The organic extracts were dried $\left(\mathrm{MgSO}_{4}\right)$ and the solvent concentrated to dryness to yield the bis[2]rotaxane $\left[\mathbf{1 7}-\mathrm{H}_{2}\right]\left[\mathrm{PF}_{6}\right]_{2}(163 \mathrm{mg}, 96 \%)$ as a light yellow powder. M.p. ${ }^{132-133}{ }^{\circ} \mathrm{C} ;{ }^{1} \mathrm{H}$ NMR $\left(\mathrm{CD}_{3} \mathrm{COCD}_{3}, 500 \mathrm{MHz}, 298 \mathrm{~K}\right): \delta=3.44(\mathrm{~s}$, $12 \mathrm{H}), 3.82-3.85(\mathrm{~m}, 16 \mathrm{H}), 4.03-4.05(\mathrm{~m}, 8 \mathrm{H}), 4.10-4.20(\mathrm{~m}, 16 \mathrm{H}), 4.71$ (brs, 8H), 6.24-6.26 (m, 8H), 6.31-6.33 (m, 4H), 6.55-6.75 (m, 16H), $8.01(\mathrm{~s}, 4 \mathrm{H}), 8.17(\mathrm{~s}, 4 \mathrm{H}), 8.85 \mathrm{ppm}(\mathrm{brs}, 4 \mathrm{H}) ;{ }^{13} \mathrm{C} \mathrm{NMR}\left(\mathrm{CD}_{3} \mathrm{COCD}_{3}\right.$, $125 \mathrm{MHz}, 298 \mathrm{~K}): \delta=49.7,52.4,54.6,67.3,70.4,71.0,71.3,100.7,106.7$, $107.7,109.9,112.2,119.2,119.7,121.1,127.9,134.1,136.9,146.5$, $160.9 \mathrm{ppm}$; HRMS (ESI): $m / z$ calcd for $\mathrm{C}_{96} \mathrm{H}_{116} \mathrm{~F}_{12} \mathrm{~N}_{8} \mathrm{O}_{18} \mathrm{P}_{2}\left[M-2 \mathrm{PF}_{6}\right]^{+}$: 834.4193; found: 834.4229. Slow evaporation of a solution of $\left[\mathbf{1 7}-\mathrm{H}_{2}\right]-$ $\left[\mathrm{PF}_{6}\right]_{2}$ in $\mathrm{CH}_{2} \mathrm{Cl}_{2} / \mathrm{EtOH}$ yielded single crystals suitable for X-ray crystallography.

[4]Rotaxane [18- $\left.\mathbf{H}_{4}\right]\left[\mathbf{P F}_{\mathbf{6}}\right]_{\mathbf{4}}$ : A solution of the tetraaldehyde $\mathbf{1 6}(11.8 \mathrm{mg}$, $0.034 \mathrm{mmol}), 2(25.9 \mathrm{mg}, 0.068 \mathrm{mmol})$, and the bisammonium salt $\left[\mathbf{9}-\mathrm{H}_{2}\right]-$ $\left[\mathrm{PF}_{6}\right]_{2}(25 \mathrm{mg}, 0.034 \mathrm{mmol})$ in $\mathrm{CD}_{3} \mathrm{NO}_{2}(2 \mathrm{~mL})$ was stirred at room temperature for $5 \mathrm{~min}$. $\mathrm{BH}_{3} \cdot \mathrm{THF}(1.8 \mathrm{M}$ in $\mathrm{THF}, 100 \mu \mathrm{l}, 0.180 \mathrm{mmol})$ was added to the mixture, which was stirred at room temperature overnight. The solvent was then evaporated and the residue was partitioned between $2 \mathrm{M} \mathrm{NaOH}$ aqueous and $\mathrm{CHCl}_{3}$. The organic extracts were dried 
and the solvent evaporated off. The residue was dissolved in $\mathrm{Me}_{2} \mathrm{CO}$ and few drops of TFA were added to the solution. The solvent was evaporated off, the residual oil was dissolved in a mixture of $\mathrm{H}_{2} \mathrm{O}$, and $\mathrm{MeCN}$ and a saturated aqueous solution of $\mathrm{NH}_{4} \mathrm{PF}_{6}$ was added. The $\mathrm{MeCN}$ was removed and the aqueous solution was extracted with $\mathrm{CH}_{2} \mathrm{Cl}_{2}$ several times. The organic extracts were then dried $\left(\mathrm{MgSO}_{4}\right)$ and the solvent was concentrated dryness to yield the [4]rotaxane $\mathbf{1 8}-4 \mathrm{H} \cdot 4 \mathrm{PF}_{6}(45 \mathrm{mg}, 75 \%)$ as a yellow powder. A portion of the product was further purified by washing with hot EtOH to recover $\left[\mathbf{1 8}-\mathrm{H}_{4}\right]\left[\mathrm{PF}_{6}\right]_{4}$ as an off-white solid. M.p. $>300{ }^{\circ} \mathrm{C}(\operatorname{decomp}) ;{ }^{1} \mathrm{H}$ NMR $\left(\mathrm{CD}_{3} \mathrm{CN}, 500 \mathrm{MHz}, 298 \mathrm{~K}\right): \delta=3.37$ (s, 24H), 3.47-3.80 (m, 40H), 4.09-4.17 (m, 24H), 4.30-4.45 (m, 24H), $4.79($ brs, $8 \mathrm{H}), 5.88(\mathrm{~d}, J=2.1 \mathrm{~Hz}, 8 \mathrm{H}), 6.28(\mathrm{t}, J=2.1 \mathrm{~Hz}, 4 \mathrm{H}), 6.49(\mathrm{t}$, $J=7.5 \mathrm{~Hz}, 8 \mathrm{H}), 6.55(\mathrm{~d}, J=7.7 \mathrm{~Hz}, 8 \mathrm{H}), 6.79(\mathrm{t}, J=7.5 \mathrm{~Hz}, 8 \mathrm{H}), 7.01-$ $7.03(\mathrm{~m}, J=16 \mathrm{H}), 7.40(\mathrm{~s}, 8 \mathrm{H}), 7.77(\mathrm{~s}, 8 \mathrm{H}), 9.13 \mathrm{ppm}(\mathrm{brs}, 8 \mathrm{H})$; ${ }^{13} \mathrm{C} \mathrm{NMR}\left(\mathrm{CD}_{3} \mathrm{NO}_{2}, 125 \mathrm{MHz}, 298 \mathrm{~K}\right): \delta=54.6,67.6,70.4,70.8,71.1$, $100.9,107.0,110.4,113.1,119.6,120.3,120.9,127.8,130.0,137.0,138.0$ 147.1, $159.1161 .0 \mathrm{ppm}$; HRMS (ESI): $m / z$ calcd for $\mathrm{C}_{172} \mathrm{H}_{204} \mathrm{~F}_{24} \mathrm{~N}_{16} \mathrm{O}_{28} \mathrm{P}_{4}$ $\left[M-4 \mathrm{PF}_{6}\right]^{4+}:$ 735.3723; found: 735.3752 .

X-ray crystallography: Table 1 summarizes the crystallographic data. The intensity data were collected on Bruker Smart 1000 CCD-based X-ray diffractometer, radiation $\mathrm{Mo}_{\mathrm{K} \alpha}(\lambda=0.71073 \AA)$; absorption correction :

\section{Acknowledgements}

This research was supported by a National Science Foundation (NSF) grant (CHE 0317170) and two NSF equipment grants (CHE 9974928 and CHE 0092036).

[1] Catenanes are molecules comprised of two (or more) ring-shaped components that are interlocked like links in a chain, see: a) G. Schill, Catenanes, Rotaxanes and Knots, Academic Press, New York, 1971; b) Molecular Catenanes, Rotaxanes and Knots (Eds.: J.-P. Sauvage, C. Dietrich-Buchecker), Wiley-VCH, Weinheim, 1999; for recent examples of kinetic syntheses of catenanes, see: c) D. G. Hamilton, M. Montalti, L. Prodi, M. Fontani, P. Zanello, J. K. M. Sanders, Chem. Eur. J. 2000, 6, 608-617; d) Q. Y. Li, E. Vogel, A. H. Parham, M. Nieger, M. Bolte, R. Fröhlich, P. Saarenketo, K. Rissanen, F. Vögtle, Eur. J. Org. Chem. 2001, 4041-4049; e) L. Z. Yan, P. E. Dawson, Angew. Chem. 2001, 113, 3737-3739; Angew. Chem. Int. Ed. 2001, 40, 3625-3627; f) P. R. Ashton, V. Baldoni, V. Balzani, A. Credi, H. D. A. Hoffmann, M.-V. Martínez-Diáz, F. M. Raymo, J. F. Stoddart, M. Venturi, Chem. Eur. J. 2001, 7, 3482-3492; g) F. Biscarini, M. Cavallini, D. A Leigh, S. León, S. J. Teat, J. K. Y. Wong, F. Zerbetto, J. Am. Chem. Soc. 2002, 124, 225-233; h) L. Raehm, J.-M. Kern, J.-P. Sauvage, C. Hamann, C. Palacin, J.-P. Bourgoin, Chem. Eur. J. 2002, 8, 2153-2162; i) H.-R. Tseng, S. A. Vignon, P. C. Celestre, J. F. Stoddart, A. J. P. White, D. J. Williams, Chem. Eur. J. 2003, 9, 543-546; j) P. Mobian, J.-M. Kern, J.-P. Sauvage, J. Am. Chem. Soc. 2003, 125, 2016-2017; k) P. Mobian, J.M. Kern, J.-P. Sauvage, Angew. Chem. 2004, 116, 2446-2449; Angew. Chem. Int. Ed. 2004, 43, 2392-2395; l) J. V. Hernandez E. R. Kay, D. A. Leigh, Science 2004, 306, 1532-1537.

[2] Rotaxanes are molecules comprised of one (or more) wheelshaped component(s) that is (are) trapped mechanically along the axle(s) of one (or more) dumbbell-shaped component(s). See references $[1 \mathrm{a}, \mathrm{b}]$. For recent examples of the kinetic syntheses of rotaxanes, see: a) C. A. Schalley, G. Silva, C. F. Nising, P. Linnartz, Helv. Chim. Acta 2002, 85, 1578 1596 ; b) C. A. Stainer, S. J. Alderman, T. D. W. Claridge, H. L. Anderson, Angew. Chem. 2002, 114,

semiempirical. The frames were integrated with the Bruker SAINT-program system ${ }^{[38 a]}$ by using a narrow-frame integration algorithm. The structures were solved by direct methods and refined based on $F^{2}$ using the SHELXTL software package. ${ }^{[38 b]}$ CCDC-263073-CCDC-263075 contain the supplementary crystallographic data for this paper. These data can be obtained free of charge from The Cambridge Crystallographic Data Centre via www.ccdc.cam.ac.uk/data_request/cif.
1847-1850; Angew. Chem. Int. Ed. 2002, 41, 1769-1772; c) M. Andersson, M. Linke, J.-C. Chambron, J. Davidson, V. Heitz, L. Hammarström, J.-P. Sauvage, J. Am. Chem. Soc. 2002, 124, 4347-4362; d) M. Asakawa, T. Ikeda, N. Yui, T. Shimizu, Chem. Lett. 2002, 174175; e) J. M. Mahoney, R. Shukla, R. A. Marshall, A. M. Beatty, J. Zajicek, B. D. Smith, J. Org. Chem. 2002, 67, 1436-1440; f) M. Asakawa, G. Brancato, M. Fanti, D. A. Leigh, T. Shimizu, A. M. Z. Slawin, J. K. Y. Wong, F. Zerbetto, S. Zhang, J. Am. Chem. Soc. 2002, 124, 2939-2950; g) J. O. Jeppesen, K. A. Nielsen, J. Perkins, S. A. Vignon, A. Di Fabio, R. Ballardini, M. T. Gandolfi, M. Venturi, V. Balzani, J. Becher, J. F. Stoddart, Chem. Eur. J. 2003, 9, 29823007; h) K. Nikitin, B. Long, D. Fitzmaurice, Chem. Commun. 2003, $282-283$; i) T. Iijima, S. A. Vignon, H.-R. Tseng, T. Jarrosson, J. K. M. Sanders, F. Marchioni, M. Venturi, E. Apostoli, V. Balzani, 
J. F. Stoddart, Chem. Eur. J. 2004, 10, 6375-6392; j) J. O. Jeppesen, S. Nygaard, S. A. Vignon, J. F. Stoddart, Eur. J. Org. Chem. 2005, $196-220$

[3] The simplest example of a knot is a trefoil knot. A molecular trefoil knot is a single macrocycle threaded internally in such a manner that it comprises three overcrosses, all of one and the same absolute stereochemistry and all of one and the opposite absolute stereochemistry, that is, it exists in enantiomeric forms. For recent examples of molecular trefoil knots, see: a) C. O. Dietrich-Buchecker, J.P. Sauvage, Angew. Chem. 1989, 101, 192-194; Angew. Chem. Int. Ed. Engl. 1989, 28, 189-192; b) R. F. Carina, C. O. Dietrich-Buchecker, J.-P. Sauvage, J. Am. Chem. Soc. 1996, 118, 9110-9116; c) G. Rapenne, C Dietrich-Buchecker, J.-P. Sauvage, J. Am. Chem. Soc. 1999, 121, 994-1001; d) L.-E. Perret-Aebi, A. von Zelewsky, C. Dietrich-Buchecker, J.-P. Sauvage, Angew. Chem. 2004, 116, $4582-$ 4585; Angew. Chem. Int. Ed. 2004, 43, 4482-4485; e) P. R. Ashton, O. A. Matthews, S. Menzer, F. M. Raymo, N. Spencer, J.-F. Stoddart, D. J. Williams, Liebigs Ann./Recl. 1997, 2485-2494; f) C. A. Hunter, P. C. Mayers, Nature 2001, 411, 763; g) F. Vögtle, A. Hünten, E. Vogel, S. Buschbeck, O. Safarowsky, J. Recker, A.-H. Parham, M. Knott, W. M. Müller, U. Müller, Y. Okamoto, T. Kubota, W. Lindner, E. Francotte, S. Grimme, Angew. Chem. 2001, 113, 2534-2537; Angew. Chem. Int. Ed. 2001, 40, 2468-2471; h) O. Lukin, W. M. Müller, U. Müller, A. Kaufmann, C. Schmidt, J. Leszczynski, F. Vögtle, Chem. Eur. J. 2003, 9, 3507-3517; i) O. Lukin, T. Kubota, Y. Okamoto, A. Kaufmann, F. Vögtle, Chem. Eur. J. 2004, 10, 28042810.

[4] a) C. Mao, W. Sun, N. C. Seeman, Nature 1997, 386, 137-138; b) K. S. Chichak, S. J. Cantrill, A. R. Pease, S.-H. Chiu, G. W. V. Cave, J. L. Atwood, J. F. Stoddart, Science 2004, 304, 1308-1312; c) J. S. Siegel, Science 2004, 304, 1256-1258; d) C. A. Schalley, Angew. Chem. 2004, 116, 4499-4501; Angew. Chem. Int. Ed. 2004, 43, 4399-4401.

[5] S. J. Cantrill, K. S. Chichak, A. J. Peters, J. F. Stoddart, Acc. Chem. Res. 2005, 38, 1-9.

[6] Bistable catenanes and rotaxanes have been employed as switches in a range of devices and across different environments. See: a) C. P. Collier, G. Mattersteig, E. W. Wong, Y. Luo, K. Beverly, J. Samapio, F. M. Raymo, J. F. Stoddart, J. R. Heath, Science 2000, 289, 11721175 ; b) A. R. Pease, J. O. Jeppesen, J. F. Stoddart, Y. Luo, C. P. Collier, J. R. Heath, Acc. Chem. Res. 2001, 34, 433-444; c) Y. Luo, C. P. Collier, J. O. Jeppesen, K. A. Nielsen, E. DeIonno, G. Ho, J. Perkins, H.-R. Tseng, T. Yamamoto, J. F. Stoddart, J. R. Heath, ChemPhysChem 2002, 3, 519-525; d) M. R. Diehl, D. W. Steuerman, H.-R. Tseng, S. A. Vignon, A. Star, P. C. Celestre, J. F. Stoddart, J. R. Heath, ChemPhysChem 2003, 4, 1335-1339; e) H.-R. Tseng, D. Wu, N. X. Fang, X. Zhang, J. F. Stoddart, ChemPhysChem 2004, 5, 111116; f) D. W. Steuerman, H.-R. Tseng, A. J. Peters, A. H. Flood, J. O. Jeppesen, K. A. Nielsen, J. F. Stoddart, J. R. Heath, Angew. Chem. 2004, 116, 6648-6653; Angew. Chem. Int. Ed. 2004, 43, 64866491; g) A. H. Flood, A. J. Peters, S. A. Vignon, D. W. Steuerman, H.-R. Tseng, S. Kang, J. R. Heath, J. F. Stoddart, Chem. Eur. J. 2004, 10, 6558-6564; h) A. H. Flood, J. F. Stoddart, D. W. Steuerman, J. R. Heath, Science 2004, 306, 2055-2056; i) S. S. Jang, Y. H. Kim, W. A. Goddard III, A. H. Flood, B. W. Laursen, H.-R. Tseng, J. F. Stoddart, J. O. Jeppesen, J. W. Choi, D. W. Steuerman, E. DeIonno, J. R. Heath, J. Am. Chem. Soc. 2005, 127, 1563-1575.

[7] For an example of the statistical approach see: a) E. Wasserman, $J$. Am. Chem. Soc. 1960, 82, 4433-4434; b) H. L. Frisch, E, Wasserman, J. Am. Chem. Soc. 1961, 83, 3789-3795; c) I. T. Harrison, J. Chem. Soc. Chem. Commun. 1972, 231-232; d) G. Schill, W. Beckmann, F. H. Schweikert, Chem. Ber. 1986, 119, 2647-2655.

[8] For example of the use of covalent templates, see: a) G. Schill, H. Zollenkopf, Justus Liebigs Ann. Chem. 1969, 721, 53-74; b) G. Schill, C. Zürcher, Chem. Ber. 1977, 110, 2046-2066; c) G. Schill, K. Rissler, H. Fritz, Ber. Chem. Ber. 1986, 119, 1374-1399; d) K. Hiratani, J. Suga, Y. Nagawa, H. Houjou, H. Tokuhisa, M. Numata, K. Watanabe, Tetrahedron Lett. 2002, 43, 5747-5750; e) N. Kameta, K. Hiratani, Y. Nagawa, Chem. Commun. 2004, 466-467.
[9] For reviews on coordinative templating approaches to the construction of mechanically interlocked molecular compounds, see: a) J.-C. Chambron, J.-P. Sauvage, Chem. Eur. J. 1998, 4, 1362-1366; b) A Niemz, V. M. Rotello, Acc. Chem. Res. 1999, 32, 41-52; c) L. Fabbrizzi, M. Licchelli, P. Pallavicini, Acc. Chem. Res. 1999, 32, 846853; d) D. A. Leigh, A. Murphy, Chem. Ind. 1999, 178-183; e) P. Piotrowiak, Chem. Soc. Rev. 1999, 28, 143-150; f) M.-J. Blanco, M. C. Jiménez, J.-C. Chambron, V. Heitz, M. Linke, J.-P. Sauvage, Chem. Soc. Rev. 1999, 28, 293-305; g) M D. Ward, Chem. Ind. 2000, 22-26; h) M.-J. Blanco, J.-C. Chambron, M. C. Jiménez, J.-P. Sauvage, Top. Stereochem. 2003, 23, 125-173.

[10] For recent examples of mechanically interlocked molecular compounds formed by dynamic noncovalent chemistry, see: a) C. A Hunter, C. M. R. Low, M. J. Packer, S. E. Spey, J. G. Vinter, M. O. Vysotsky, G. Zonta, Angew. Chem. 2001, 113, 2750-2754; Angew. Chem. Int. Ed. 2001, 40, 2678-2682; b) A. Hori, K. Kumazawa, T. Kusukawa, D. K. Chand, M. Fujita, S. Sakamoto, K. Yamaguchi, Chem. Eur. J. 2001, 7, 4142-4149; c) S.-Y. Chang, J. S. Choi, K.-S. Jeong, Chem. Eur. J. 2001, 7, 2687-2697; d) A. Hori, A. Akasawa, K. Biradha, S. Sakamoto, K. Yamaguchi, M. Fujita, Angew. Chem. 2002, 114, 2403-2406; Angew. Chem. Int. Ed. 2002, 41, 3269-3272; e) C. P. McArdle, M. J. Irwin, M. C. Jennings, J. J. Vittal, R. J. Puddephatt, Chem. Eur. J. 2002, 8, 723-734; f) A. Hori, H. Kataoka, T. Okano, S. Sakamoto, K. Yamaguchi, M. Fujita, Chem. Commun. 2003, 182-183; g) K.-S. Jeong, E.-J. Park, J. Org. Chem. 2004, 69 2618-2621; h) T. J. Burchell, D. J. Eisler, R. J. Puddephatt, Dalton Trans. 2005, 268-272.

[11] a) D. H. Busch, N. A. Stephenson, Coord. Chem. Rev. 1999, 100, 139-154; b) S. Anderson, J. K. M. Sanders, Acc. Chem. Res. 1993, 26, 469-475; c) R. Cacciapaglia, L. Mandolini, Chem. Soc. Rev. 1993, 22, 221-231; d) R. Hoss, F. Vögtle, Angew. Chem. 1994, 106, 389-398; Angew. Chem. Int. Ed. Engl. 1994, 33, 374-384; e) J. P. Schneider, J. W. Kelly, Chem. Rev. 1995, 95, 2169-2187; f) F. M. Raymo, J. F. Stoddart, Pure Appl. Chem. 1996, 68, 313-322; g) Templated Organic Synthesis (Eds.: F. Diederich, P. J. Stang), WileyVCH, Weinheim, 1999; h) J. F. Stoddart, H.-R. Tseng, Proc. Natl. Acad. Sci. USA 2002, 99, 4797-4800.

[12] For some recent examples from our own research, see: a) S. J. Cantrill, D. A. Fulton, M. C. T. Fyfe, J. F. Stoddart, A. J. P. White, D. J. Williams, Tetrahedron Lett. 1999, 40, 3669-3672; b) S. J. Rowan, S. J. Cantrill, J. F. Stoddart, Org. Lett. 1999, 1, 129-132; c) S.-H. Chiu, S. J. Rowan, S. J. Cantrill, J. F. Stoddart, A. J. P. White, D. J. Williams, Chem. Eur. J. 2002, 8, 5170-5183.

[13] B. Fuchs, A. Nelson, A. Star, J. F. Stoddart, S. Vidal, Angew. Chem. 2003, 115, 4352-4356; Angew. Chem. Int. Ed. 2003, 42, 4220-4242.

[14] For examples of the use of esters in dynamic covalent chemistry, see: a) P. A. Brady, J. K. M. Sanders, J. Chem. Soc. Perkin Trans. 1997, 3237-3253; b) S. J. Rowan, J. K. M. Sanders, J. Org. Chem. 1998, 63, 1536-1546; c) G. Kaiser, J. K. M. Sanders, Chem Commun. 2000, 1763-1764; d) P. S. Lukeman, J. K. M. Sanders, Tetrahedron Lett. 2000, 41, 10171-10174.

[15] For rotaxanes containing disulfide units in their dumbbell-shaped components that are formed by riveting and stoppering approaches, see: a) A. G. Kolchinski, N. W. Alcock, R. A. Roesner, D. H. Busch, Chem. Commun. 1998, 1437-1438; b) Y. Furusho, T. Hasegawa, A. Tsuboi, N. Kihana, T. Takata, Chem. Lett. 2000, 18-19; c) T. Oku, T. Furusho, T. Takata, J. Polym. Sci. Part A 2003, 41, 119-123; for examples of the use of disulfide groups in other molecular self-assembly processes, see: d) H. Hioki, W. C. Still, J. Org. Chem. 1998, 63, 904-905; e) S.-W. Tam-Chang, J. S. Stehouwer, J. Hao, J. Org. Chem. 1999, 64, 334-335; f) S. Otto, R. L. E. Furlan, J. K. M. Sanders, J. Am. Chem. Soc. 2000, 122, 12063-12064; g) O. Ramström, J.M. Lehn, ChemBioChem 2000, 1, 41-48; h) S. Otto, R. L. E. Furlan, J. K. M. Sanders, Science 2002, 297, 590-593; i) for the use of disulfide groups in the amplification of a catalyst from a dynamic combinatorial library, see: B. Brisig, J. K. M. Sanders, S. Otto, Angew. Chem. 2003, 115, 1308-1311; Angew. Chem. Int. Ed. 2003, 42, 1270 1273. 
[16] For examples of catenanes incorporating metal-ligand coordination within their macrocyclic components, see: a) M. Fujita, F. Ibukuro, H. Hagaira, K. Ogura, Nature 1994, 367, 720-725; for examples of rotaxanes incorporating metal-ligand interactions within their dumbbell-shaped components that are formed by threading-followed-by-stoppering approaches, see: b) A. J. Baer, D. H. Macartney, Inorg. Chem. 2000, 39, 1410-1417; c) K. Chichak, M. C. Walsh, N. R. Branda, Chem. Commun. 2000, 847-848; d) M. J. Gunter, N. Bampos, K. D. Johnstone, J. K. M. Sanders, New J. Chem. 2001, 25, 166-173; for examples of rotaxanes incorporating metal-ligand interactions within their macrocyclic components that are formed by clipping reactions, see references $[10 \mathrm{a}, \mathrm{c}]$; for recent examples of metal-ligand coordination guiding other molecular self-assembly processes, see: e) E. Stulz, Y.-F. Ng, S. M. Scott, J. K. M. Sanders, Chem. Commun. 2002, 524-525; f) Y. Kubota, S. S. Sakamoto, K. Yamaguchi, M. Fujita, Proc. Natl. Acad. Sci. USA 2002, 99, 48544856.

[17] For an example of a [2]catenane synthesis employing ring-opening and ring-closing metathesis (RORCM) and operating under thermodynamic control, see; a) T. J. Kidd, D. A. Leigh, A. J. Wilson, J. Am. Chem. Soc. 1999, 121, 1599-1600; for an example of a [2]catenane synthesis utilizing ring-closing metathesis (RCM), see: b) M. Weck, B. Mohr, J.-P. Sauvage, R. H. Grubbs, J. Org. Chem. 1999, 64, 54635471; for examples of [2]rotaxane syntheses using RCM, see: c) J. A. Wisner, P. D. Beer, M. G. B. Drew, M. R. Sambrook, J. Am. Chem. Soc. 2002, 124, 12469-12476; d) A. F. M. Kilbinger, S. J. Cantrill, A. W. Waltman, M. W. Day, R. H. Grubbs, Angew. Chem. 2003, 115, 3403-3407; Angew. Chem. Int. Ed. 2003, 42, 3281-3285.

[18] a) J.-M. Lehn, Supramolecular Chemistry, VCH, Weinheim, 1995; b) H.-J. Schneider, A. Yatsimirsky, Principles and Methods in Supramolecular Chemistry, Wiley-VCH, Weinheim, 2000; c) J. W. Steed, J. L. Atwood, Supramolecular Chemistry, Wiley-VCH, Weinheim, 2000; d) L. F. Lindoy, I. M. Atkinson, Self-Assembly in Supramolecular Systems (Ed.: J. F. Stoddart), RSC, Cambridge, 2000; e) J.-M. Lehn, Science 2002, 295, 2400-2403; f) D. N. Reinhoudt, M. CregoCalama, Science 2002, 295, 2403-2407.

[19] a) J. S. Lindsey, New J. Chem. 1991, 15, 153-180; b) D. Philp, J. F. Stoddart, Synlett. 1991, 445-458; c) D. S. Lawrence, T. Jiang, M. Levitt, Chem. Rev. 1995, 95, 2229-2260; d) D. Philp, J. F. Stoddart, Angew. Chem. 1996, 108, 1242-1286; Angew. Chem. Int. Ed. Engl. 1996, 35, 1154-1195; e) P. J. Stang, B. Olenyuk, Acc. Chem. Res. 1997, 30, 502-518; f) M. M. Conn, J. Rebek, Jr, Chem. Rev. 1997, 97, 1647-1668; g) B. Linton, A. D. Hamilton, Chem. Rev. 1997, 97, 1669-1680; h) M. Fujita, Chem. Soc. Rev. 1998, 27, 417-425; i) D. T. Bong, T. D. Clark, J. R. Granja, M. R. Ghadiri, Angew. Chem. 2001, 113, 1016-1041; Angew. Chem. Int. Ed. 2001, 40, 988, 1011; j) L. J. Prins, D. N. Reinhoudt, P. Timmerman, Angew. Chem. 2001, 113, 2446-2492; Angew. Chem. Int. Ed. 2001, 40, 2382-2426; k) L. M. Greig, D. Philp, Chem. Soc. Rev. 2001, 30, 287-302; 1) Science 2002, 295, 2400-2421 (Viewpoint on Supramolecular Chemistry and SelfAssembly)

[20] M. C. T. Fyfe, J. F. Stoddart, Acc. Chem. Res. 1997, 30, 393-401.

[21] S. J. Rowan, S. J. Cantrill, G. R. L. Cousins, J. K. M. Sanders, J. F. Stoddart, Angew. Chem. 2002, 114, 938-993; Angew. Chem. Int. Ed. 2002, 41, 898-952.
[22] T. Chang, A. M. Heiss, S. J. Cantrill, M. C. T. Fyfe, A. R. Pease, S. J. Rowan, J. F. Stoddart, D. J. Williams, Org. Lett. 2000, 2, 2943-2946.

[23] For an exception, see: J. D. Badjic, S. J. Cantrill, R. H. Grubbs, E. N. Guidry, R. Orenes, J. F. Stoddart, Angew. Chem. 2004, 116, $3335-$ 3340; Angew. Chem. Int. Ed. 2004, 43, 3273-3278.

[24] a) W. R. Layer, Chem. Rev. 1963, 63, 489-510; b) S. Dayagi, Y. Degani, In The Chemistry of the Carbon-Nitrogen Double Bond (Ed.: S. Patai) Interscience, New York, 1970, pp. 64-83; for an example of how the reversible nature of imine bond formation can be exploited in conjunction with molecular recognition to alter the product selectivity in a dynamic combinatorial library, see: c) I. Huc, J.-M. Lehn, Proc. Natl. Acad. Sci. USA 1997, 94, 2106-2110.

[25] For an example of [2]rotaxane formation as a result of imine hydrolysis/formation in the dumbbell component, see: S. J. Cantrill, S. J. Rowan, J. F. Stoddart, Org. Lett. 1999, 1, 1363-1366.

[26] For an example of [2]rotaxane formation as a result of imine exchange in the dumbbell component, see: S. J. Rowan, J. F. Stoddart, Org. Lett. 1999, 1, 1913-1916.

[27] The reversible nature of imine bond exchange in $\mathrm{CHCl}_{3}$ solution has been exploited in swapping substituted for unsubstituted $m$-phenylenediamine units in dynamic hemicarcerands and hemicarceplex (with release of entrapped guest molecules) octaimines. See: S. Ro, S. J. Rowan, A. R. Pease, D. J. Cram, J. F. Stoddart, Org. Lett. 2000 , 2, 2411-2414

[28] P. T. Glink, A. I. Oliva, J. F. Stoddart, A. J. P. White, D. J. Williams, Angew. Chem. 2001, 113, 1922-1927; Angew. Chem. Int. Ed. 2001, 40, 1870-1875.

[29] M. Horn, J. Ihringer, P. T. Glink, J. F. Stoddart, Chem. Eur. J. 2003 , 9, 4046-4054.

[30] S. J. Cantrill, A. R. Pease, J. F. Stoddart, J. Chem. Soc. Dalton Trans. 2000, 3715-3734.

[31] The extraction with $\mathrm{CHCl}_{3}$ after the deprotonation with aqueous $\mathrm{NaOH}$, followed by reprotonation with TFA of the residue from the $\mathrm{CHCl}_{3}$ extract, are all essential to the success of this rapid and efficient purification procedure.

[32] M. C. T. Fyfe, J. N. Lowe, J. F. Stoddart, D. J. Williams, Org. Lett 2000, 2, 1221-1224.

[33] K. C.-F. Leung, F. Aricó, S. J. Cantrill, J. F. Stoddart, J. Am. Chem. Soc. 2005, 127, 5808-5810.

[34] A. M. Elizarov, S.-H. Chiu, P. T. Glink, J. F. Stoddart, Org. Lett. 2002, 4, 679-682.

[35] M. Loï, E. Graf, M. W. Hosseini, A. De Cian, J. Fischer, Chem. Commun. 1999, 603-604.

[36] H. Takalo, J. Kankare, J. Heterocycl. Chem. 1990, 27, 167-169.

[37] D. D. Perrin, W. F. L. Armarego, Purification of Laboratory Chemicals; Pergamon Press: New York 1998.

[38] a) SAINT PC Version 6.36, Bruker Axs Inc., 5465 East Cheryl Parkway, Madison, WI, USA; b) SHELTL PC Version 6.12, Bruker Axs Inc., 5465 East Cheryl Parkway, Madison, WI, USA.

Received: February 10, 2005 Published online: May 11, 2005 